\title{
Charipinae Dalla Torre \& Kieffer, 1910 (Hymenoptera: Cynipoidea: Figitidae) from the Mercantour National Park (Alpes-Maritimes, France), with descriptions of three new species
}

\author{
Mar FERRER-SUAY \\ Universitat de Barcelona, \\ Facultat de Biologia, Departament de Biologia Animal, \\ Avda. Diagonal 645, E-08028 Barcelona (Spain) \\ mar.ferrer.suay@gmail.com \\ (corresponding author) \\ Jesús SELFA \\ Universitat de València, \\ Facultat de Ciències Biològiques, Departament de Zoologia, \\ Campus de Burjassot-Paterna, Dr Moliner 50, \\ E-46100 Burjassot (València) (Spain) \\ jesus.selfa@uv.es \\ Claire VILLEMANT \\ Muséum national d'Histoire naturelle, \\ Département de systématique et évolution - UMR 7205, \\ Case postale 50, 57 rue Cuvier F-75231 Paris Cedex 05 (France) \\ villeman@mnhn.fr \\ Juli PUJADE-VILLAR \\ Facultat de Biologia, Departament de Biologia Animal, \\ Avda. Diagonal 645, E-08028 Barcelona (Spain) \\ jpujade@ub.edu
}

Published on 27 March 2015 urn:Isid:zoobank.org:pub:A452D294-BA01-4C5B-9B0B-77B4079BFF1C

Ferrer-Suay M., Selfa J., Villemant C. \& Pujade-Villar J. 2015. - Charipinae Dalla Torre \& Kieffer, 1910 (Hymenoptera: Cynipoidea: Figitidae) from the Mercantour National Park (Alpes-Maritimes, France), with descriptions of three new species, in Daugeron C., Deharveng L., Isaia M., Villemant C. \& Judson M. (eds), Mercantour/Alpi Marittime All Taxa Biodiversity Inventory. Zoosystema 37 (1): 115-138. http://dx.doi.org/10.5252/z2015n1a5

\section{ABSTRACT}

Charipinae Dalla Torre \& Kieffer, 1910 material collected during the ATBI of the Mercantour National Park in the Alpes-Maritimes (France) has been studied. Based on the study of 362 specimens, 35 species in four genera have been identified from: 23 Alloxysta Förster, 1869; 10 Phaenoglyphis Förster, 1869; one Apocharips Fergusson, 1986 and one Dilyta Förster, 1869. Of these, 19 species are recorded from France for the first time: Alloxysta abdera Fergusson, 1986; Alloxysta arcuata (Kieffer, 1902); Alloxysta brachycera Hellén, 1963; Alloxysta brevis (Thomson, 1962); Alloxysta fracticornis (Thomson, 1862); Alloxysta mullensis (Cameron, 1883); Alloxysta pilipennis (Hartig, 1840); Alloxysta postica (Hartig, 1841); Alloxysta proxima Belizin, 1962; Apocharips trapezoidea (Hartig, 1841); Phaenoglyphis abbreviata (Thomson, 1877); Phaenoglyphis americana Baker, 1896; Phaenoglyphis calverti Andrews, 1978; Phaenoglyphis evenhuisi Pujade-Villar \& Paretas-Martínez, 2006; Phaenoglyphis fuscicornis (Thomson, 


KEY WORDS
Alloxysta,
Alps,
Taxonomy,
ATBI,
new species.
MOTS CLÉS Alloxysta, Alpes,
Taxonomie,

espèces nouvelles.
1877); Phaenoglyphis gutierrezi Andrews, 1978; and Phaenoglyphis longicornis (Hartig, 1840). All the Charipinae species identified are briefly described and compared with one another. Three new species are described and illustrated in detail: Alloxysta alpina Ferrer-Suay \& Pujade-Villar, n. sp.; Alloxysta franca Ferrer-Suay \& Pujade-Villar, n. sp. and Alloxysta pilae Ferrer-Suay, n. sp. A key to the species of Charipinae known from the Mercantour National Park is provided.

\section{RÉSUMÉ}

Faune des Charipinae Dalla Torre \& Kieffer, 1910 (Hymenoptera: Cynipoidea: Figitidae) du Parc national du Mercantour (Alpes-Maritimes, France), avec la description de trois nouvelles espèces.

L'étude de 362 Charipinae Dalla Torre \& Kieffer, 1910 collectés dans le Parc national du Mercantour (Alpes-Maritimes, France) dans le cadre de l'ATBI Mercantour a permis l'identification de 35 espèces dans quatre genres : 23 Alloxysta Förster, 1869; 10 Phaenoglyphis Förster, 1869; un Apocharips Fergusson, 1986 et un Dilyta Förster, 1869. 19 d'entre elles sont nouvelles pour la faune de France : Alloxysta abdera Fergusson, 1986; Alloxysta arcuata (Kieffer, 1902); Alloxysta brachycera Hellén, 1963; Alloxysta brevis (Thomson, 1962); Alloxysta fracticornis (Thomson, 1862); Alloxysta mullensis (Cameron, 1883); Alloxysta pilipennis (Hartig, 1840); Alloxysta postica (Hartig, 1841); Alloxysta proxima Belizin, 1962; Apocharips trapezoidea (Hartig, 1841); Phaenoglyphis abbreviata (Thomson, 1877); Phaenoglyphis americana Baker, 1896; Phaenoglyphis calverti Andrews, 1978; Phaenoglyphis evenhuisi Pujade-Villar \& ParetasMartínez, 2006; Phaenoglyphis fuscicornis (Thomson, 1877); Phaenoglyphis gutierrezi Andrews, 1978 and Phaenoglyphis longicornis (Hartig, 1840). Toutes les espèces recensées sont décrites brièvement et comparées entre elles. Trois espèces nouvelles : Alloxysta alpina Ferrer-Suay, n. sp.; Alloxysta franca Ferrer-Suay \& Pujade-Villar, n. sp. et Alloxysta pilae Ferrer-Suay, n. sp. font l'objet d'une description détaillée et leurs principaux caractères morphologiques sont illustrés. Une clé d'identification des espèces de Charipinae présentes dans le Parc national du Mercantour est également fournie.

\section{INTRODUCTION}

Charipinae Dalla Torre \& Kieffer, 1910 (Cynipoidea: Figitidae) are very small wasps characterized by a very shiny and smooth body, but very few diagnostic features (Ferrer-Suay et al. 2012a). These peculiarities and the great number of species described over the years have led to the current chaotic taxonomic state of this subfamily. Charipinae are all secondary parasitoids of aphids via Aphidiinae Haliday, 1833 (Hymenoptera: Braconidae) and Aphelininae Thomson, 1876 (Hymenoptera: Aphelinidae) or secondary parasitoids of psyllids via Encyrtidae Walker, 1837 (Hymenoptera: Chalcidoidea) (Menke \& Evenhuis 1991). They are economically very important in being able to counteract the biological control performed by primary parasitoids.

Charipinae have been recorded in all biogeographic regions. They have a wide continental and insular distribution, mainly in temperate areas, ranging from above the Arctic Circle (Lapland and Alaska) to $47^{\circ} \mathrm{S}$ in Argentina; some representatives have been found at $2750 \mathrm{~m}$ a.s.l. (Andrews 1978). In this wide range, however, their distribution is restricted to areas where aphids and primary parasitoids are present.

Eight valid genera are currently recognized in Charipinae: Alloxysta Förster, 1869 (cosmopolitan), Apocharips Fergusson, 1986 (cosmopolitan, but not recorded from Australia), Dilapothor Paretas-Martínez \& Pujade-Villar, 2006 (Australia), Dilyta Förster, 1869 (cosmopolitan), Lobopterocharips
Paretas-Martínez \& Pujade-Villar, 2007 (Nepal), Lytoxysta Kieffer, 1909 (North America), Phaenoglyphis Förster, 1869 (cosmopolitan), and Thoreauana Girault, 1930 (Australia). Alloxysta and Phaenoglyphis are the most speciose and widespread genera within the subfamily, respectively containing 111 and 31 currently valid species (Ferrer-Suay et al. 2012a).

During the course of the ATBI Mercantour project 362 Charipinae specimens have been collected in Malaise traps. They represent 35 species, of which 19 are recorded for the first time from France and three are new for science. We describe and illustrate here all these species and provide a key to the Charipinae species recorded in the Mediterranean Alps.

\section{MATERIAL AND METHODS}

The specimens examined here were collected in the framework of the "Terrestrial Invertebrates fieldwork module" of the ATBI Mercantour project. The Mediterranean Alps (Mercantour/Alpi Marittime) lie at a crossroads of climatic and biogeographical factors (continental, Alpine, Mediterranean and Ligurian), and encompasses a wide diversity of altitudes, exposures, geological formations and pedological substrates (Deharveng et al. 2015, this volume).

Insect collection was performed between 2009 and 2011 using a pair of standard (black and white) Malaise traps set up less than $100 \mathrm{~m}$ from each other at each sampling site. 
TABLE 1. - Sample codes and general information on the location of the sampling sites (all in Alpes-Maritimes, 06), their main vegetation and the sampling period.

\begin{tabular}{|c|c|c|c|c|c|c|c|c|c|}
\hline Sample codes & Year & $\begin{array}{l}\text { Sampling } \\
\text { period }\end{array}$ & District & Sample site & Vegetation & Altitude & Longitude & Latitude & $\begin{array}{l}\text { Nb of } \\
\text { samples }\end{array}$ \\
\hline $\begin{array}{l}\text { M09-BOR1400- } \\
\text { T1/T8-M1 }\end{array}$ & 2009 & 11.VI-15.X & $\begin{array}{l}\text { St-Martin- } \\
\text { Vésubie }\end{array}$ & Le Boréon & $\begin{array}{l}\text { Meadows and spruce } \\
\text { forest }\end{array}$ & 1540 & 7.2871439 & 44.1146875 & 8 (T1-T8) \\
\hline $\begin{array}{l}\text { M09-BOR14006- } \\
\text { T1/T8-M2 }\end{array}$ & 2009 & 11.VI-15.X & $\begin{array}{l}\text { St-Martin- } \\
\text { Vésubie }\end{array}$ & Le Boréon & $\begin{array}{l}\text { Meadows and spruce } \\
\text { forest }\end{array}$ & 1549 & 7.2890533 & 44.1143415 & 8 (T1-T8) \\
\hline $\begin{array}{l}\text { M09-BOR2000- } \\
\text { T1/T8-M1 }\end{array}$ & 2009 & 10.VI-15.X & Valdeblore & Col de Salèse & $\begin{array}{l}\text { Meadows, rhododendrons, } \\
\text { larch and spruce forest }\end{array}$ & 2058 & 7.23698 & 44.13734 & 8 (T1-T8) \\
\hline $\begin{array}{l}\text { M09-BOR2000- } \\
\text { T1/T8-M2 }\end{array}$ & 2009 & 10.VI-15.X & Valdeblore & Col de Salèse & Larch forest & 2032 & 7.2352837 & 44.1388598 & 8 (T1-T8) \\
\hline $\begin{array}{l}\text { M09-SES1400- } \\
\text { T1/T8-M1 }\end{array}$ & 2009 & 9.VI-15.X & $\begin{array}{l}\text { St-Dalmas- } \\
\text { le-Selvage }\end{array}$ & $\begin{array}{l}\text { Vallon de } \\
\text { St-Dalmas: } \\
\text { La Buisse }\end{array}$ & $\begin{array}{l}\text { Meadows, broadleaved } \\
\text { and larch forest }\end{array}$ & 1437 & 6.8875257 & 44.2848357 & 8 (T1-T8) \\
\hline $\begin{array}{l}\text { M09-SES1400- } \\
\text { T1/T8-M2 }\end{array}$ & 2009 & 9.VI-15.X & $\begin{array}{l}\text { St-Dalmas- } \\
\text { le-Selvage }\end{array}$ & $\begin{array}{l}\text { Vallon de } \\
\text { St-Dalmas: } \\
\text { La Buisse }\end{array}$ & $\begin{array}{l}\text { Meadows, broadleaved } \\
\text { and larch forest }\end{array}$ & 1421 & 6.8867683 & 44.2850731 & 8 (T1-T8) \\
\hline $\begin{array}{l}\text { M09-SES2000- } \\
\text { T1/T8-M1 }\end{array}$ & 2009 & 8.VI-15.X & $\begin{array}{l}\text { St-Dalmas- } \\
\text { le-Selvage }\end{array}$ & $\begin{array}{l}\text { Bois de } \\
\text { Sestrière }\end{array}$ & Larch forest & 1966 & 6.8240421 & 44.2927562 & 8 (T1-T8) \\
\hline $\begin{array}{l}\text { M09-SES2000- } \\
\text { T1/T8-M2 }\end{array}$ & 2009 & 8.VI-15.X & $\begin{array}{l}\text { St-Dalmas- } \\
\text { le-Selvage }\end{array}$ & $\begin{array}{l}\text { Bois de } \\
\text { Sestrière }\end{array}$ & Larch forest & 2011 & 6.8228732 & 44.2925219 & 8 (T1-T8) \\
\hline $\begin{array}{c}\text { M10-CAl1400- } \\
\text { T1/T7-M1 }\end{array}$ & 2010 & 1.VII-15.X & Saorge & $\begin{array}{l}\text { Forêt de } \\
\text { Caïros: } \\
\text { Vallerasse }\end{array}$ & Fir forest & 1379 & 7.45615 & 44.00338 & 7 (T1-T7) \\
\hline $\begin{array}{c}\text { M10-CAl1400- } \\
\text { T1/T7-M2 }\end{array}$ & 2010 & 1.VII-15.X & Saorge & $\begin{array}{l}\text { Forêt de } \\
\text { Caïros: } \\
\text { Vallerasse }\end{array}$ & Fir forest & 1387 & 7,45692 & 44,00343 & 7 (T1-T7) \\
\hline $\begin{array}{c}\text { M10-CAI2000- } \\
\text { T1/T7-M1 }\end{array}$ & 2010 & 30.VI-15.X & Saorge & $\begin{array}{l}\text { Tête de la } \\
\text { Poudrière }\end{array}$ & Larch forest & 1953 & 7.42407 & 44.01454 & 7 (T1-T7) \\
\hline $\begin{array}{c}\text { M10-CAI2000- } \\
\text { T1/T7-M1 }\end{array}$ & 2010 & 30.VI-15.X & Saorge & $\begin{array}{l}\text { Tête de la } \\
\text { Poudrière }\end{array}$ & Larch forest & 1992 & 7,42459 & 44,01388 & 7 (T1-T7) \\
\hline
\end{tabular}

TABLE 2. - Codes and dates of the successive sampling periods for each sampling site.

\begin{tabular}{|c|c|c|c|c|c|c|c|c|c|}
\hline Site & Year & T1 & T2 & T3 & T4 & T5 & T6 & T7 & T8 \\
\hline BOR 1400 M1 \& M2 & 2009 & $11-24 . \mathrm{VI}$ & 24.VI-9.VII & 9-24.VII & 24.VII-13.VIII & 13-27.VIII & 27.VIII-18.IX & $18 . I X-5 / X$ & $5-15 / X$ \\
\hline BOR 2000 M1 \& M2 & 2009 & 10-24.VI & 24.VI-9.VII & 9-24.VII & 24.VII-13.VIII & 13-27.VIII & 27.VIII-18.IX & 18.IX-5/X & $5-15 / X$ \\
\hline SES 1400 M1 \& M2 & 2009 & 9-30.VI & 30.VI-10.VII & 10-23.VII & 23.VII-7.VIII & 7-19.VIII & 19.VIII-22.IX & $22 . I X-7 / X$ & $7-15 / X$ \\
\hline SES 2000 M1 \& M2 & 2009 & 8-24.VI & 24.VI-10.VII & 10-23.VII & 23.VII-7.VIII & 7-19.VIII & 19.VIII-22.IX & 22.IX-7/X & $7-15 / X$ \\
\hline CAI $1400 \mathrm{M} 1$ \& M2 & 2010 & 1-16.VII & 16-31.VII & 31.VII-16.VIII & 16.VIII-30.VIII & ).VIII-15.IX & 15-30.IX & $30.1 X-15 / X$ & - \\
\hline CAI 2000 M1 \& M2 & 2010 & 30.VI-16.VII & 16-31.VII & 31.VII-16.VIII & 16.VIII-30.VIII & 30.VIII-15.IX & $15-30.1 X$ & $30.1 X-15 / X$ & - \\
\hline
\end{tabular}

Sampling site locations varied from year to year, but in a given valley two sites were always selected: one between 1400-1500 $\mathrm{m}$ and the other at about $2000 \mathrm{~m}$ a.s.l. These paired sampling sites were located in the Saint-Martin-deVésubie and Saint-Delmas-le-Selvage districts (Alpes-Maritimes) in 2009 (4 sampling sites), in the Saorgue district (Alpes-Maritimes) in 2010 (2 sampling sites) (Fig. 1) and finally in the Meyronnes and Larche districts (Alpes-deHaute-Provence) in 2011 (2 sampling sites) but these samples were not taken into account in this study. Traps were emptied every two weeks from about June to October, along a number of weeks varying from year to year depending on the climatic conditions (mainly snowfall) at the beginning and end of the sampling period (Deharveng et al. 2015, this volume).

The Charipinae studied here come only from the 2009 and 2010 samples. All samples collected from a given Malaise trap were labelled using a coding system where " $\mathrm{M}$ " refers to Mercantour, "9" or " 10 " indicates the sampling year, "BOR", "SES" or "CAI" the sampling area, "1400/1500 or 2000 " the sampling altitude, T1 to T8 the sequence of the successive sampling periods and "M1 or M2" the different Malaise traps of each pair. Detailed information on the trap locations and geographic coordinates, the sampling periods and the main vegetation present at the sampling sites are given in Table 1 . The codes and corresponding dates of the successive sampling periods for each sampling site are given in Table 2.

Specimens were studied using stereomicroscopy (NIKON SMZ-1). The field-emission gun environmental scanning electron microscope (FEI Quanta 200 ESEM) was used for high-resolution imaging without gold-coating of the specimens.

Most of specimens are deposited at MNHN (Muséum national d'Histoire naturelle, Paris, France; curator C. Villemant), the rest of the material being housed at the University of Barcelona (UB) (Pujade-Villar pers. col.). 


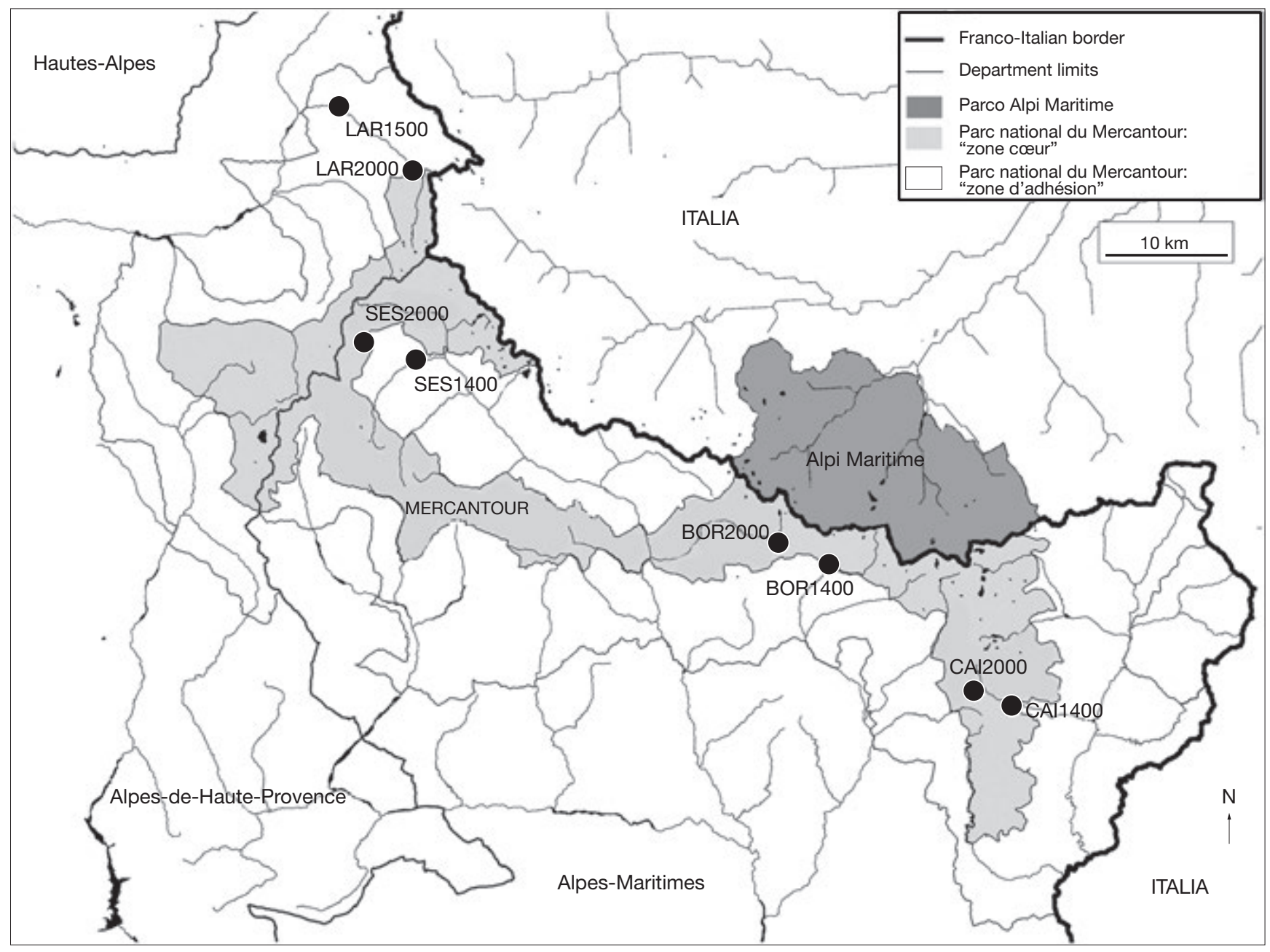

FIG. 1. - Locations of the Malaise traps set up in the Mercantour National Park in 2009 (BOR1400, BOR2000, SES1400 and SES2000) and 2010 (CAI1400 and CAI2000) and 2011 (LAR1400 and LAR2000) (see Table 1 for details) as well as in 2011 in Meyronnes (LAR1400) and Larche districts (LAR2000).

Morphological terms follow Paretas-Martínez et al. (2007). Measurements and abbreviations include F1-F12: first and subsequent flagellomeres. Measurements in antennal formulae are given as length (width): from pedicel to F4 (F4-F12 are subequal in these species). Measurements were made with the microscope, using an ocular micrometer. The width of the forewing radial cell is measured from the margin of the wing to the base of Rs vein. The transfacial line is the distance between the inner margins of the compound eyes, measured across the face through the antennal sockets. The malar space is the distance from the mandible basis to the ventral margin of the compound eye. Females and males have the same morphology, unless otherwise indicated.

\section{RESULTS}

Species are presented in alphabetical order. Sample code numbers are used to indicate the collection details of the non Type material examined. The reader is referred to Tables 1 and 2 for the corresponding data.

\section{SYSTEMATICS}

Subphylum HEXAPODA Blainville, 1816 Class INSECTA Linnaeus, 1758

Order HYMENOPTERA Linnaeus, 1758

Suborder APOCRITA Latreille, 1810

Superfamily CYNIPOIDEA Billberg, 1820

Family FigITIDAE Thomson, 1862

Subfamily CHARIPINAE Dalla Torre \& Kieffer, 1910 Genus Alloxysta Förster, 1869

Alloxysta abdera Fergusson, 1986 (Figs 2A; 3A)

Alloxysta abdera Fergusson, 1986: 10.

MATERIAL EXAMINED. - (5\%). M10-CAI2000-T1-M1: 3 ; M10CAI2000-T5-M2: 2\%. $3 \%$ deposited at MNHN and $2 \%$ at UB.

Distribution. - Previously known from England (Fergusson 1986). First record from France.

Hosts. - Unknown. 

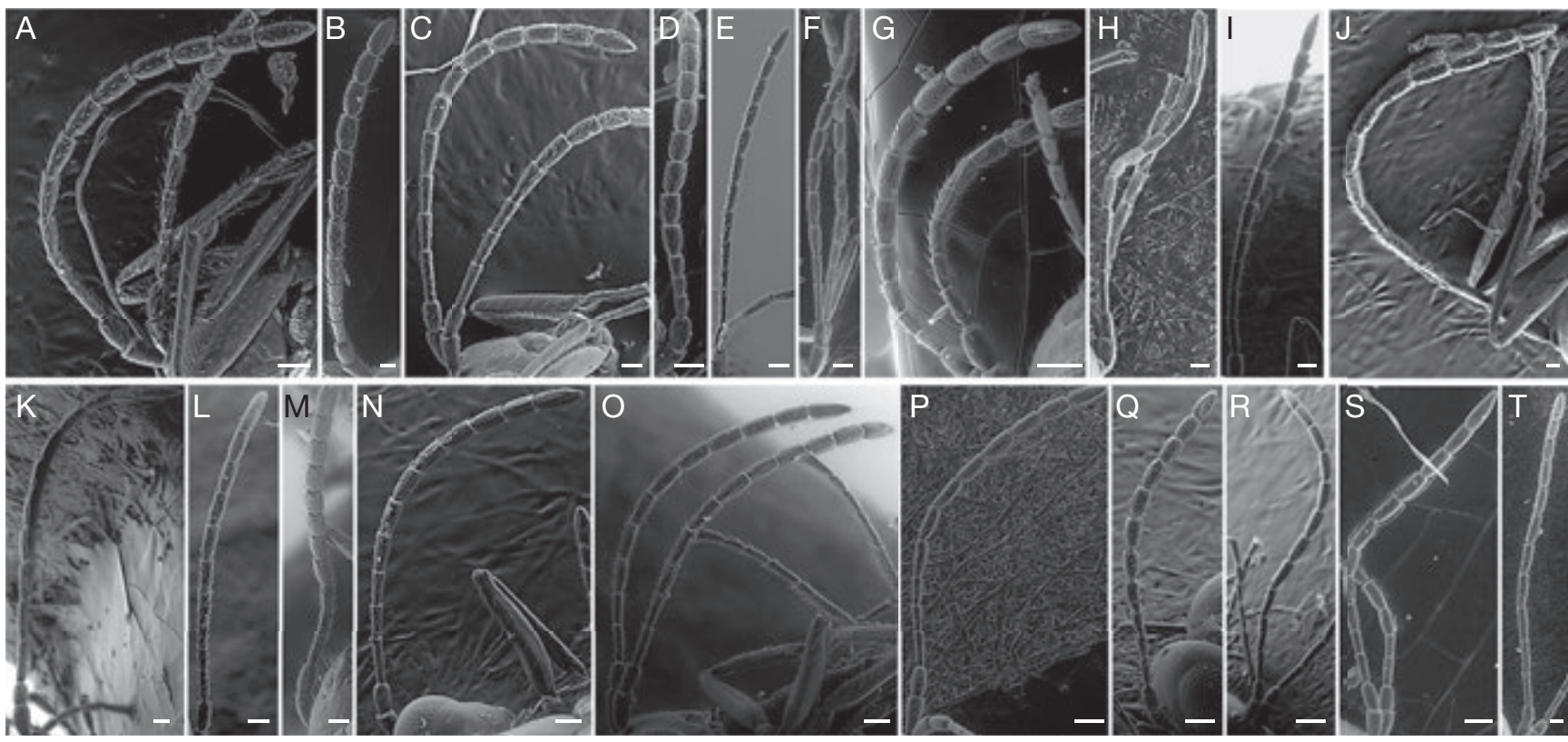

FIG. 2. - Types of Alloxysta Förster, 1869 antennae: A, A. abdera Fergusson, 1986; B, A. arcuata (Kieffer, 1902); C, A. brachycera Hellén, 1963; D, A. brevis (Thomson, 1862); E, A. castanea (Hartig, 1841); F, A. circumscripta (Hartig, 1841); G, A. citripes (Thomson, 1862); H, A. fracticornis (Thomson, 1862); I, A. consobrina (Zetterstedt, 1838); J, A. longipennis (Hartig, 1841); K, A. macrophadna (Hartig, 1841); L, A. melanogaster (Hartig, 1840); M, A. mullensis (Cameron, 1883); N, A. nigrita (Thomson, 1862); O, A. obscurata (Hartig, 1840); P, A. pilipennis (Hartig, 1840); Q, A. postica (Hartig, 1841); R, A. proxima Belizin, 1962; S, A. pusilla (Kieffer, 1902); T, A. victrix (Westwood, 1833). Scale bars: $50 \mu \mathrm{m}$.

DiagnOSIS. - Alloxysta abdera is characterized by its completely open radial cell, being $2.2 \times$ longer than wide in both male and female; pronotal and propodeal carinae present; female antenna with rhinaria beginning from $\mathrm{F} 4$, F1 longer than pedicel and subequal to F2, F2 longer than F3, F3 slightly longer than F4 (Fig. 2A); male antenna with rhinaria beginning from F2, F2 curved, F1 longer than pedicel and F2, F2 shorter than F3, F3 subequal to F4. Similar to Alloxysta pallidicornis (Curtis, 1838), but the two species can be differentiated by: 1) flagellomeres proportions in female: $\mathrm{F} 2$ longer than F3, F3 slightly longer than F4 in A. abdera, whereas F2-F4 are subequal in length in $A$. pallidicornis; 2) shape of propodeal carinae: forming a plate with apical setae and sides slightly curved in $A$. abdera, whereas the two well defined carinae are basally joined and apically separated in $A$. pallidicornis and 3 ) the proportions of the radial cell: $2.2 \times$ longer than wide in $A$. abdera (Fig. $3 \mathrm{~A}$ ), versus $2.6 \times$ in A. pallidicornis.

\section{Alloxysta alpina \\ Ferrer-Suay \& Pujade-Villar, n. sp.}

(Fig. 4)

TYPE MATERIAL. - (3\%). Holotype. 9 (MNHN) labelled M9SES2000-T5-M2, Saint-Dalmas-le-Selvage, Vallon de Sestrière, larch forest, Alt: 2011, 07-19.VIII.2009: 1 \% .

Paratypes. 2 (MNHN, UB) labelled M9-SES2000-T3-M2, Saint-Dalmas-le-Selvage, Vallon de Sestrière, larch forest, Alt: 2011 10-23.VII.2009: 1\%; M10-CAI1400-T4-M2, Forêt de Caïros, fir forest, Alt: 1387, 16-30.VIII.2010: 1오.

ETYMOLOGY. - The new species is named after the mountain range where it was first found.

DisTribution. - France.

Hosts. - Unknown.
DiAgNOSIs. - Alloxysta alpina Ferrer-Suay \& Pujade-Villar, n. sp. is characterized by a completely open radial cell $3.8 \times$ longer than wide, pronotal carinae present, propodeal carinae absent, female antenna with rhinaria beginning from F4, and F2 longer than F1 and F3. It is similar to Alloxysta mara Paretas-Martínez \& Pujade-Villar, 2005, but the two species can be differentiated by flagellomere proportions: F2 longer than F1 and F3 in A. alpina Ferrer-Suay \& Pujade-Villar, n. sp., but F1-F3 subequal in length in $A$. mara.

\section{DESCRIPTION}

Length

Female (Fig. 4D): 0.9-1.2 mm. Male unknown.

\section{Coloration}

Head, mesosoma and metasoma yellowish brown. Antenna yellow, darkening towards apex. Legs yellow and veins yellowish brown.

\section{Head}

Transversely ovate, smooth and shiny, slightly wider than high in front view. Setae dense on face below and between toruli, scattered above toruli and on vertex. Transfacial line $1.1 \times$ height of compound eye. Malar space $0.4 \times$ height of compound eye.

\section{Antenna}

Female: 13-segmented, filiform. All antennomeres covered with sparse setae. F1-F3 smooth and thinner than remaining flagellomeres; F4-F11 with rhinaria, club shaped. Antennal formula: 2.0 (1.1); $2.8(0.6) ; 3.0(0.6) ; 2.8(0.6) ; 3.1(0.9)$ (Fig. 4C). 

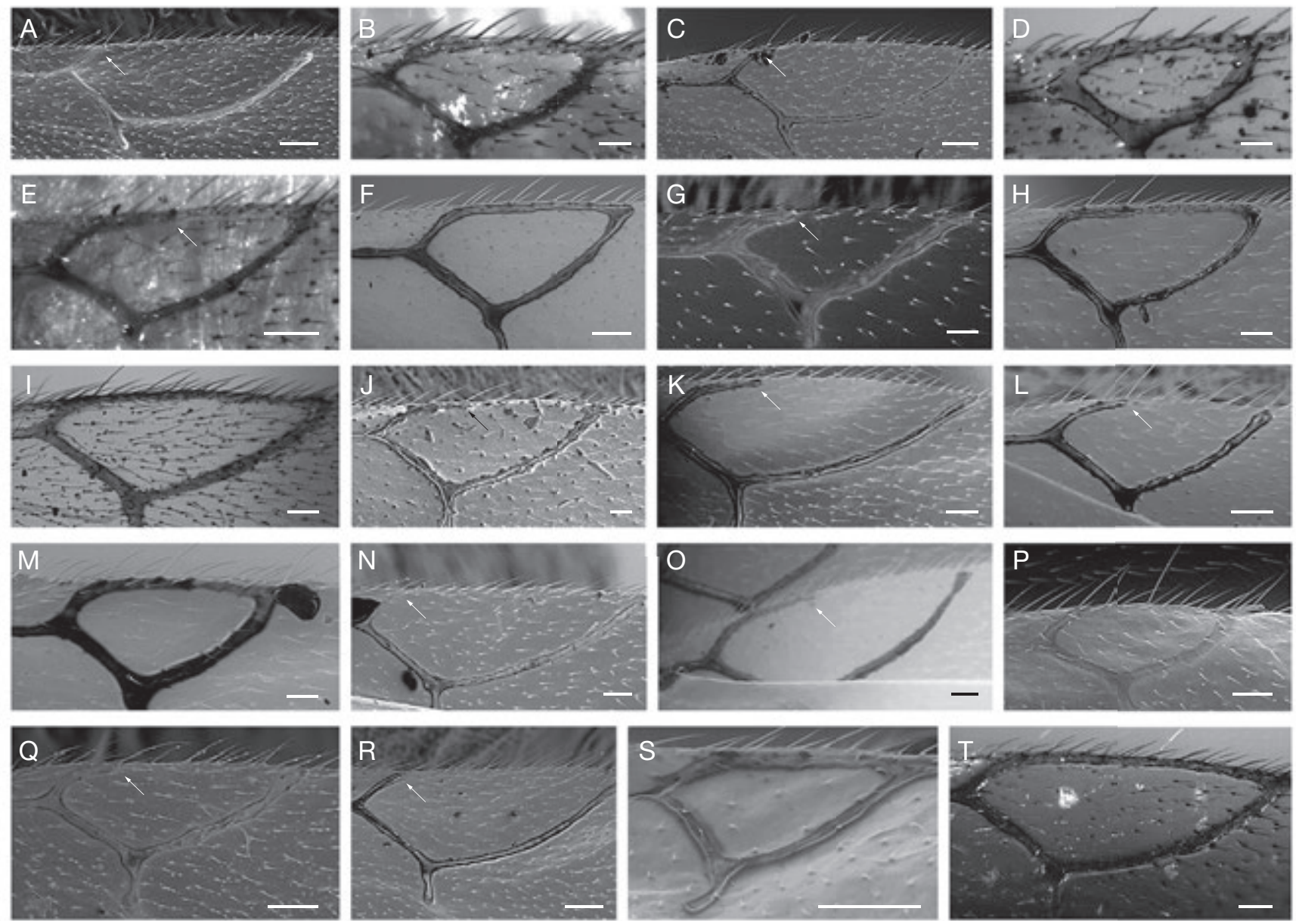

FIG. 3. - Types of Alloxysta Förster, 1869 radial cells: A, A. abdera Fergusson, 1986; B, A. arcuata (Kieffer, 1902); C, A. brachycera Hellén, 1963; D, A. brevis (Thomson, 1862); E, A. castanea (Hartig, 1841); F, A. circumscripta (Hartig, 1841); G, A. citripes (Thomson, 1862); H, A. fracticornis (Thomson, 1862); I, A. consobrina (Zetterstedt, 1838); J, A. longipennis (Hartig, 1841); K, A. macrophadna (Hartig, 1841); L, A. melanogaster (Hartig, 1840); M, A. mullensis (Cameron, 1883); N, A. nigrita (Thomson, 1862); O, A. obscurata (Hartig, 1840); P, A. pilipennis (Hartig, 1840); Q, A. postica (Hartig, 1841); R, A. proxima Belizin, 1962; S, A. pusilla (Kieffer, 1902); T, A. victrix (Westwood, 1833). Scale bars: $50 \mu \mathrm{m}$.

\section{Mesosoma}

Pronotum with two lateral carinae, densely setose with distolateral corners less hairy (Fig. 4E). Mesoscutum smooth and shiny, round in dorsal view with few scattered setae and two lines of setae on both sides. Scutellum smooth and shiny with scattered setae more abundant apically. Height of mesopleural triangle along anterior margin $1.5 \times$ the height of mesopleuron. Propodeum densely setose and without carinae (Fig. 4B).

\section{Forewing}

Longer than body, $1.7 \times$ longer than mesosoma and metasoma together, densely setose; marginal setae present (Fig. 4A). Radial cell open, $3.8 \times$ longer than wide (Fig. 4A). R1 short and slightly curved; Rs long and slightly curved.

\section{Metasoma}

Proximal part with an incomplete ring of setae, glabrous centrally and wider laterally. Rest of metasoma smooth and shiny, with terga clearly visible.
Alloxysta arcuata (Kieffer, 1902)

(Figs 2B; 3B; 5A; 6A)

Allotria (Allotria) arcuata Kieffer, 1902a: 12.

Material eXAmined. - (23\%). M09-BOR1400-T4-M1: 19 ; M09-BOR2000-T4-M1: 2\%; M09-SES1400-T2-M1: 1\%; M09SES1400-T5-M1: 1\%; M09-SES1400-T1-M2: 5\%; M09-SES1400-T2M2: 1; M09-SES1400-T3-M2: 1 \% M09-SES2000-T5-M2: 1; M10-CAI1400-T2-M1: 1\%; M10-CAI1400-T1-M2: 2\%; M10-CAI1400-T2-M2: 1\%; M10-CAI1400-T7-M1: 2क; M10CAI2000-T1-M1: 1\%; M10-CAI2000-T4-M1: 2\%; M10CAI2000-T6-M2: 1ㅇ․ Material deposited at UB except for 8 우 deposited at MNHN.

Distribution. - Previously known from the Palaearctic (FerrerSuay et al. 2012b). First record from France.

Hosts. - See Charipinae Worldwide Catalogue (Ferrer-Suay et al. 2012a).

DiAGNOSIS. - Alloxysta arcuata is characterized by: small closed radial cell, $2.3 \times$ longer than wide (Fig. $3 \mathrm{~B}$ ), pronotal carinae present (Fig. 5A), propodeal carinae forming a plate (Fig. 6A), female antenna with rhinaria beginning from F3; F1 subequal to pedicel and longer 

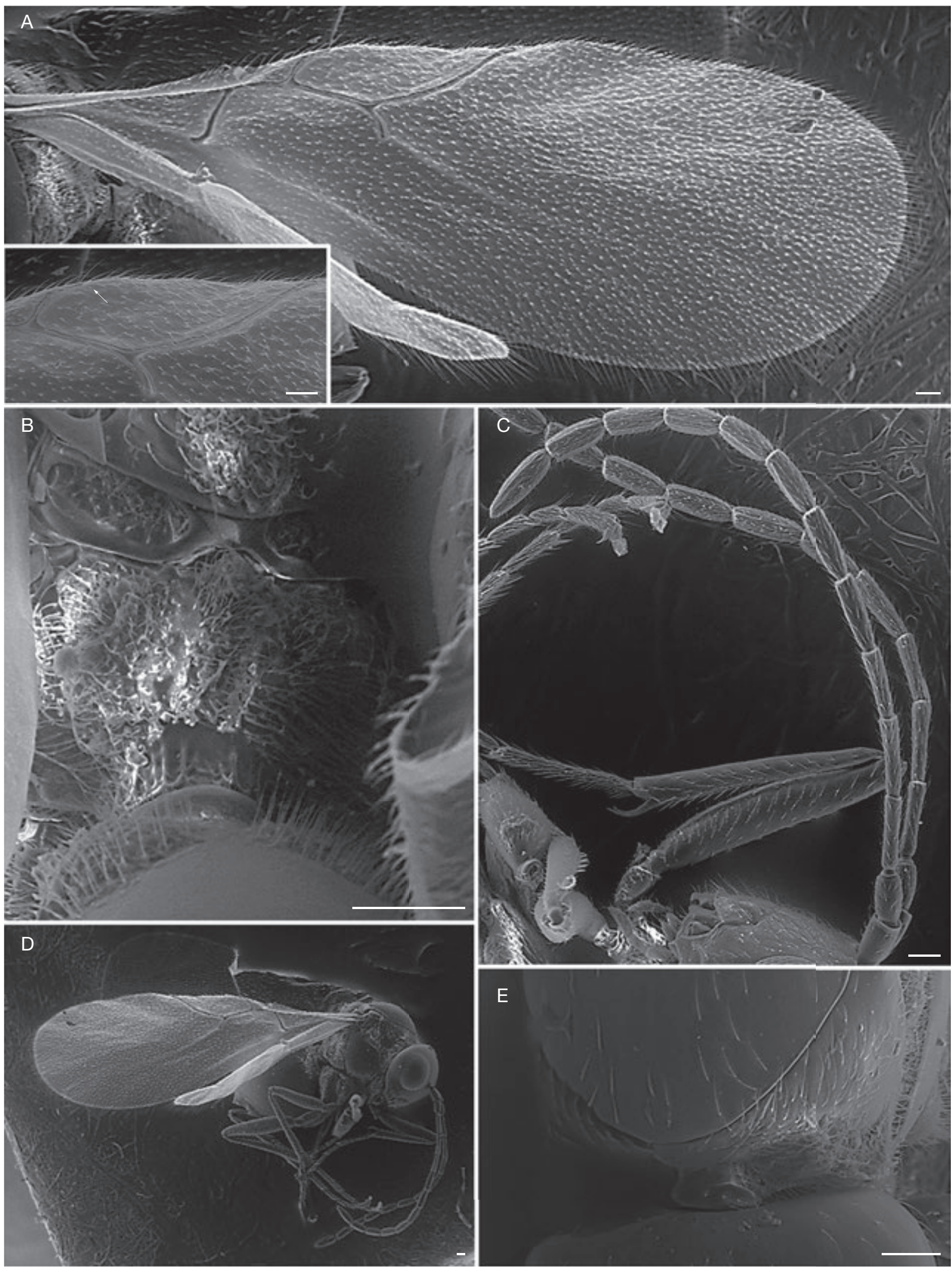

FIG. 4. - Alloxysta alpina Ferrer-Suay \& Pujade-Villar, n. sp.: A, Forewing; B, propodeum; C, antennae; D, body; E, pronotum. Scale bars: 50 ㅆm. 
than F2, F2 subequal to F3 (Fig. 2B), male antenna with rhinaria beginning from F2, F2 slightly curved, F1 longer than pedicel, F1 subequal to F2, F2 shorter than F3. It is similar to Alloxysta ramulifera (Thomson, 1862), but the two species can be differentiated by: rhinaria beginning from $\mathrm{F} 3$ in $A$. arcuata and from $\mathrm{F} 4$ in $A$. ramulifera; pronotal carinae well defined and visible in $A$. arcuata, rather than small and sometimes difficult to see under the pubescence in $A$. ramulifera; radial cell $2.3 \times$ longer than wide in A. arcuata (Fig. 3B), but only $2.0 \times$ in $A$. ramulifera; propodeal carinae with curved sides in $A$. arcuata, but with straight sides in $A$. ramulifera.

Alloxysta brachycera Hellén, 1963

(Figs 2C; 3C)

Alloxysta brachycera Hellén, 1963: 14.

Material EXAMINED. - (11\%). M09-BOR1400-T3-M1: 4\%; M09-BOR1400-T5-M1: 1; M09-BOR2000-T4-M1: 2ㅇ M09-SES2000-T3-M1: 1\%; M09-SES2000-T5-M1: 1\%; M10CAI2000-T1-M1: 19; M10-CAI2000-T3-M1: 1․ Material deposited at MNHN, except for $5 \circ$ deposited at UB.

Distribution. - Previously known from Finland (Hellén 1963). First record from France.

Hosts. - Unknown.

DiAgNOSIS. - Alloxysta brachycera is characterized by: a completely open radial cell, $2.7 \times$ longer than wide (Fig. $3 \mathrm{C}$ ), pronotal carinae present, propodeal carinae absent, female antenna with rhinaria beginning from F4, F1 longer than pedicel and F2, F2 longer than F3, F3 shorter than F4 (Fig. 2C). Male unknown. Similar to Alloxysta nigrita (Thomson, 1862), but the two species can be differentiated by: $\mathrm{F} 2$ longer than F3 in $A$. brachycera (Fig. 2C), whereas $\mathrm{F} 2$ is shorter than $\mathrm{F} 3$ in $A$. nigrita (Fig. $2 \mathrm{~N}$ ); proportions of radial cell: $2.7 \times$ longer than wide in $A$. brachycera (Fig. $3 \mathrm{C}$ ), versus $2.9 \times$ in A. nigrita (Fig. $3 \mathrm{~N}$ ).

\section{Alloxysta brevis (Thomson, 1862)}

(Figs 2D; 3D; 5B)

Allotria brevis Thomson, 1862: 408.

MATERIAL EXAMINED. - (21). M9-BOR1400-T1-M1: 19 ; M9-BOR1400-T3-M1: 1\%; M9-BOR1400-T5-M1: 1; M9-BOR2000-T3-M1: 1\%; M9-BOR2000-T4-M2: 1 ; M9-BOR2000-T5-M2: 19; M9-SES1400-T3-M1: 1 \% : M9SES1400-T2-M2: 2\%; M9-SES1400-T3-M2: 3\%; M9-SES1400-T4M2: 1; M9-SES1400-T6-M2: 3ㅇ M9-SES2000-T3-M1: 1 ; M9-SES2000-T4-M1: 1\%; M9-SES2000-T3-M2: 1\%; M10CAI1400-T5-M2: 1\%; M10-CAI1400-T4-M2: 1․ Material deposited at MNHN, except for $10 \%$ deposited at UB.

Distribution. - Previously known from the Palaearctic (FerrerSuay et al. 2012b). First record from France.

Hosts. - See Charipinae Worldwide Catalogue (Ferrer-Suay et al., 2012a).

DiAGNOSIS. - Alloxysta brevis is characterized by: a small closed radial cell, $2.1 \times$ longer than wide (Fig. 3D), pronotal carina absent (Fig. 5B), propodeal carinae present forming a plate; female and male antenna with rhinaria beginning from F4; F1 shorter than pedicel and F1-F3 subequal in length (Fig. 2D). It is similar to Alloxysta darci (Girault, 1933), but could be differentiated by: antenna shorter than body in $A$. brevis, versus longer in $A$. darci; forewing with marginal setae shorter in $A$. brevis than those in $A$. darci.
Alloxysta castanea (Hartig, 1841)

(Figs 2E; 3E)

Xystus castaneus Hartig, 1841: 352.

Material eXAMINED. - (105ㅇ). M9-BOR1400-T1-M1: 1역 M9-BOR1400-T2-M1: 4; M9-BOR1400-T3-M1: 1 ; BOR1400-T4-M1: 1; BOR1400-T5-M1: 1; BOR1400-T6M1: 4\%; BOR1400-T8-M1: 1\%; M9-BOR1400-T2-M2: 9; M9-BOR1400-T8-M2: 1연 M9-BOR2000-T2-M1: 1; M9-BOR2000-T3-M1: 5; M9-BOR2000-T4-M1: 2\%; M9-BOR2000-T6-M1: 3ㅇ M9-SES1400-T5-M1: 1우 M9SES1400-T1-M2: 2\%; M9-SES1400-T2-M2: 7\%; M9-SES1400-T3M2: 12; M9-SES1400-T4-M2: 1 ; M9-SES1400-T6-M2: 3\%; M9-SES1400-T8-M209: 2; M9-SES2000-T3-M1: 4; M9-SES2000-T4-M1: 10; M9-SES2000-T5-M1: 4ㅇ : M9SES2000-T4-M2: 1\%; M9-SES2000-T6-M2: 1\%; M10-CAI1400-T2M1: 1\%; M10-CAI1400-T5-M1: 1क; M10-CAI1400-T6-M1: 3; M10-CAI1400-T7-M1: 2; M10-CAI1400-T1-M2: 2웅 M10-CAI1400-T2-M2: 1\%; M10-CAI1400-T3-M2: $1 \%$; M10CAI1400-T4-M2: 2\%;M10-CAI1400-T6-M2:2\%;M10-CAI1400-T7M2: 1\%; M10-CAI2000-T1-M1: 2\%; M10-CAI2000-T6-M1: 1\%; M10-CAI2000-T1-M2: 1\%; M10-CAI2000-T2-M2: 1 \%; M10CAI2000-T3-M2: 2\%. Material deposited at MNHN except for 50 ㅇ deposited at UB.

DisTRIBUTION. - Species known from the Holarctic region (FerrerSuay et al. 2012a). Previously cited in France by Kieffer (1902a: 10, 15; 1904: 595), De Gaulle (1908: 26) and Cavro (1954: 12).

Hosts. - See Charipinae Worldwide Catalogue (Ferrer-Suay et al. 2012a).

DiAGNOSIS. - Alloxysta castanea is characterized by: a partially open radial cell being $2.4 \times$ longer than wide (Fig. $3 \mathrm{E}$ ), pronotal and propodeal carinae present, male and female antenna with rhinaria beginning from F3, F2-F4 subequal in length (Fig. 2E), F1 and F2 slightly curved in male. It is similar to Alloxysta aurata Belizin, 1968 but the two species can be differentiated by the ratio between F2 and F3: F2 subequal to F3 in $A$. castanea but F2 shorter than $\mathrm{F} 3$ in $A$. aurata and the proportions of the radial cell: $2.3 \times$ longer than wide in $A$. castanea, versus $3.0 \times$ in $A$. aurata.

\section{Alloxysta circumscripta (Hartig, 1841)} (Figs 2F; 3F)

Xystus circumscriptus Hartig, 1841: 352.

Material eXAMINED. - (12ㅇ). M9-BOR1400-T1-M1: 3 ; M9-BOR1400-T3-M1: 1\%; M9-BOR1400-T8-M2: 1\%; M9BOR2000-T6-M1: 2\%; M9-SES1400-T2-M2: 4ㅇ; M9-SES2000-T4M2: 19.6 o deposited at MNHN and 69 at UB.

Distribution. - Species known from the Palaearctic region (Ferrer-Suay et al. 2012a). Previously cited from France by De Gaulle (1908: 26).

Hosts. - See Charipinae Worldwide Catalogue (Ferrer-Suay et al. 2012a).

DiAGNOSIS. - Alloxysta circumscripta is characterized by its closed radial cell being $2.5 \times$ longer than wide (Fig. $3 \mathrm{~F}$ ), pronotal carinae present, propodeal carinae absent, female antenna with rhinaria beginning from F5, F2 shorter than F3, F3 shorter than F4 (Fig. 2F), male antenna rhinaria beginning from F4, F2 longer than F3, F3 shorter than F4. It is similar to Alloxysta consobrina (Zetterstedt, 1838) but they can be differentiated by the proportion between flagellomeres: 
F1 subequal to F2, F2 shorter or subequal to F3 in $A$. circumscripta (Fig. $2 \mathrm{~F}$ ), versus $\mathrm{F} 1$ longer than $\mathrm{F} 2, \mathrm{~F} 2$ subequal to $\mathrm{F} 3$ in $A$. consobrina (Fig. 2I); proportions of radial cell: $2.5 \times$ longer than wide in A. circumscripta (Fig. 3F) but 2.7 in A. consobrina (Fig. 3I).

\section{Alloxysta citripes (Thomson, 1862)}

(Figs 2G; 3G; 6F)

Allotria citripes Thomson, 1862: 410.

MATERIAL EXAMINED. - (11\%). M9-BOR1400-T2-M1: 1\%; M9SES1400-T1-M2: 1\%; M9-SES1400-T2-M2: 1\%; M9-SES1400-T3M2: 1 ; M9-SES1400-T4-M2: 1 ; M9-SES1400-T6-M2: 1 ; M9-SES2000-T4-M1: 2웅 M9-SES2000-T2-M2: 2운 M10CAI2000-T4-M1: 1․ Material deposited at MNHN except for $5 \%$ deposited at UB.

Distribution. - Species known from the Palaearctic region (FerrerSuay et al. 2012a). Previously cited from France by Kieffer 1904a: 600 and De Gaulle 1908: 26.

Hosts. - See Charipinae Worldwide Catalogue (Ferrer-Suay et al. 2012a).

Diagnosis. - Alloxysta citripes is characterized by its partially open and small radial cell being $2.1 \times$ longer than wide (Fig. 3G), pronotal carinae present, propodeal carinae present forming a plate but not protruding, female antenna with rhinaria beginning from F4, F1 subequal to pedicel and longer than F2, F2-F4 subequal in length (Fig. 2G), male antenna with rhinaria beginning from F1, pedicel-F3 subequal, F3 slightly shorter than F4. Similar to Alloxysta postica (Hartig, 1841) but the two species can be differentiated by the shape of propodeal carinae: the carinae are not protruding in $A$. citripes (Fig. $6 \mathrm{~F}$ ), whereas they are clearly visible and forming a plate in $A$. postica; proportions of radial cell: $2.1 \times$ longer than wide in $A$. citripes (Fig. $3 \mathrm{G}$ ), versus $2.5 \times$ in A. postica (Fig. 3Q).

\section{Alloxysta consobrina (Zetterstedt, 1838)} (Figs 2I; 3I)

Cynips consobrina Zetterstedt, 1838: 410.

Material eXAMINED. - (16\%). M09-BOR2000-T4-M1: 1우 M09-SES1400-T1-M2: 4우; M09-SES1400-T2-M2: 7우; M09-SES1400-T3-M2: 2ㅇ M09-SES1400-T6-M2: 1우 M10CAI2000-T1-M1: 19 . Eight $q$ deposited at MNHN and $8 \%$ at UB.

Distribution. - Cosmopolitan. Previously cited from France by Kieffer (1902a: 16) and De Gaulle (1908: 26). Alloxysta consobrina was previously cited in France as Alloxysta fuscicornis (Hartig, 1841), a well-known cosmopolitan species. These two homonymous species were recently synonymized by Ferrer-Suay et al. (2013).

Hosts. - See Charipinae Worldwide Catalogue (Ferrer-Suay et al. 2012a).

DiAgNOSIS. - Alloxysta consobrina is characterized by: radial cell $2.7 \times$ longer than wide (Fig. $3 \mathrm{I}$ ), pronotal carinae present, propodeal carinae absent, male and female antenna with rhinaria beginning from F4, F2 longer than F3, F3 shorter than F4 (Fig. 2I), F1-F3 bowed in male. Similar to A. circumscripta, but the two species can be differentiated by the proportion between flagellomeres: F1 longer than F2, F2 subequal to F3 in A. consobrina (Fig. 2I), versus $\mathrm{F} 1$ subequal to $\mathrm{F} 2$, F2 shorter or subequal to $\mathrm{F} 3$ in $A$. circumscripta (Fig. 2F); proportions of radial cell: $2.7 \times$ longer than wide in A. consobrina (Fig. 3I) but $2.5 \times$ in A. circumscripta (Fig. 3F).
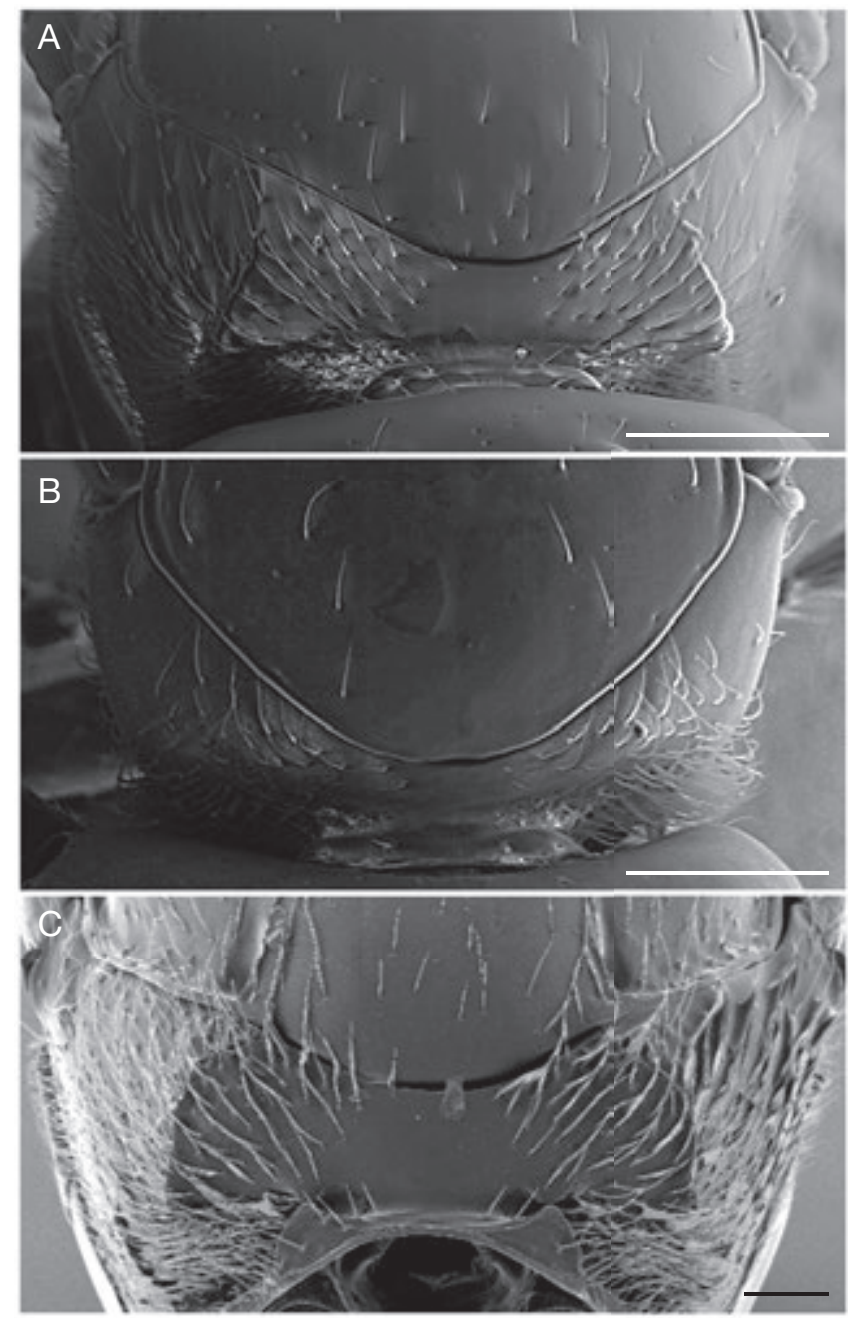

FIG. 5. - Types of pronota: A, A. arcuata (Kieffer, 1902); B, A. brevis (Thomson, 1862); C, P. americana Baker, 1896. Scale bars: $50 \mu \mathrm{m}$.

Alloxysta fracticornis (Thomson, 1862)

(Figs 2H;3H)

Allotria fracticornis Thomson, 1862: 408.

MATERIAL EXAMINED. - ( $20^{*} \&$ 8 9 ). M9-BOR1400-T4-M1: $10^{7}$; M9-SES1400-T3-M2: 2우 M9-SES1400-T6-M2: 1우 M9SES2000-T2-M1: $10^{7}$; M9-SES2000-T4-M1: 2 \% M9-SES2000-T5M1: 2क; M9-SES2000-T3-M1: 1\%. Material deposited at MNHN except for $10^{7} \& 4$ 우 deposited at UB.

Distribution. - Previously known from the Palaearctic region (Ferrer-Suay et al. 2012a). First record from France.

Hosts. - Unknown.

Diagnosis. - Alloxysta fracticornis is characterized by its closed radial cell being $2.2 \times$ longer than wide (Fig. $3 \mathrm{H}$ ), pronotal carinae absent, propodeal carinae present, male and female with rhinaria beginning from F3, F1-F3 subequal in length (Fig. 2H), F3 curved in male. Similar to Alloxysta mullensis (Cameron, 1883), but the two species can be differentiated by the ratio between $\mathrm{F} 1$ and pedicel: $\mathrm{F} 1$ longer than pedicel in $A$. fracticornis (Fig. $2 \mathrm{H}$ ), versus $\mathrm{F} 1$ subequal to pedicel in $A$. mullensis (Fig. 2M); F1-F3 subequal in length in A. fracticornis (Fig. $2 \mathrm{H}$ ) but $\mathrm{F} 1$ longer than $\mathrm{F} 2$ and $\mathrm{F} 2$ subequal 
to $\mathrm{F} 3$ in $A$. mullensis (Fig. 2M); male antenna with $\mathrm{F} 3$ curved in A. fracticornis but without any curved flagellomere in $A$. mullensis.

\section{Alloxysta franca \\ Ferrer-Suay \& Pujade-Villar, n. sp.}

(Fig. 7)

TYPE MATERIAL. - (19). Holotype 9 deposited at MNHN with the following labels: M09-BOR2000-T1-M1, Valdeblore, Col de Salèse, larch forest, Alt: 2058 m, 10-24.VI.2009.

ETYMOLOGY. - The new species is named after the country where it was first found, France.

Distribution. - France.

Hosts. - Unknown.

Diagnosis. - Alloxysta franca Ferrer-Suay \& Pujade-Villar, n. sp. is characterized by its completely open radial cell being $2.4 \times$ longer than wide, pronotal carinae absent, propodeal carinae forming a plate, female antenna with rhinaria beginning from F4, F1 longer than F2, F2 subequal in F3, F3 shorter than F4. Similar to Alloxysta pilae Ferrer-Suay n. sp., but the two species can be differentiated by the pronotal carinae: absent in $A$. franca Ferrer-Suay \& Pujade-Villar, n. sp., but present in $A$. pilae FerrerSuay, n. sp.; proportions of radial cell: $2.4 \times$ longer than wide in A. franca Ferrer-Suay \& Pujade-Villar, n. sp., vs $2.2 \times$ in A. pilae Ferrer-Suay, n. sp.

\section{DESCRIPTION}

Length

Female (Fig. 7E): 0.9 mm. Male unknown.

\section{Coloration}

Head, mesosoma and metasoma yellowish brown. Scape, pedicel, F1-F3 dark yellow, F4-F11 yellowish brown. Legs yellow and veins yellowish brown.

\section{Head}

Transversely ovate, smooth and shiny, slightly wider than high in front view. Face densely hairy; setae present below and between toruli. Frons and vertex glabrous. Transfacial line $1.4 \times$ height of compound eye. Malar space $0.6 \times$ height of compound eye.

\section{Antenna}

Female: 13-segmented, filiform. All antennomeres covered with sparse setae. F1-F3 smooth and thinner than remaining flagellomeres; F4-F11 with rhinaria and club shaped. Antennal formula: 2.5 (1.4); 2.3 (0.9); 1.7 (0.9); 1.8 (1.0); 2.8 (1.5) (Fig. 7B). Male unknown.

\section{Mesosoma}

Pronotum hairy, setae less abundant on distolateral corners, pronotum without carinae (Fig. 7D). Mesoscutum smooth and shiny, round in dorsal view, with few scattered setae and two lines of setae on both sides. Scutellum smooth and shiny with scattered setae, setae more abundant at scutellum apex. Height of mesopleural triangle along anterior margin $1.3 \times$ height of mesopleuron. Propodeum densely hairy, with two carinae present forming a plate and few setae on top (Fig. 7F).

\section{Forewing}

Longer than body, $1.5 \times$ longer than mesosoma and metasoma together. Covered with dense pubescence; marginal setae present (Fig. 7A). Open radial cell $2.4 \times$ longer than wide (Fig. 7C). R1 short and slightly curved; Rs long and straight.

\section{Metasoma}

Proximal part with an incomplete ring of setae, glabrous in the centre and wider laterally. Rest of metasoma smooth and shiny with terga clearly visible.

Alloxysta longipennis (Hartig, 1841) (Figs 2J; 3J)

Xystus longipennis Hartig, 1841: 352.

MATERIAL EXAMINED. - (10 \& 5 9 ). M09-BOR1400-T3-M1: $10^{7}$; M09-BOR1400-T5-M1: 1 \%; M09-SES1400-T3-M1: 1 \%; M09-SES2000-T3-M1: 1\%; M09-SES2000-T6-M2: 1\%; M10CAI1400-T7-M2: 1․ Material deposited at MNHN except for $2 \%$ deposited at UB.

Distribution. - Previously known from Germany (Ferrer-Suay et al. 2012a). First record from France.

Hosts. - Unknown.

DiAgNosis. - Alloxysta longipennis is characterized by: partially open radial cell, $2.6 \times$ longer than wide (Fig. $3 \mathrm{~J}$ ), pronotal and propodeal carinae present, forming a plate with straight sides, female with rhinaria beginning from F3, F1 longer than pedicel and F2, F2 subequal to F3, F3 shorter than F4 (Fig. 2J). Male unknown. Similar to Alloxysta melanogaster (Hartig, 1840), but the two species can be differentiated by the proportions between flagellomeres in female: F1 longer than pedicel and F2, F2 subequal to F3 in $A$. longipennis (Fig. 2J), whereas pedicel-F3 subequal in $A$. melanogaster (Fig. 2L); and by the size of radial cell: $2.6 \times$ longer than wide in A. longipennis (Fig. 3J), versus $2.3 \times$ in A. melanogaster (Fig. 3L).

\section{Alloxysta macrophadna (Hartig, 1841)}

(Figs $2 \mathrm{~K} ; 3 \mathrm{~K}$ )

Xystus macrophadnus Hartig, 1841: 352.

MATERIAl EXAMINED. - (10 \& 25\%). M9-BOR1400-T2-M1: 2\%; M9-BOR1400-T3-M1: 1\%; M9-BOR2000-T4-M1: 2\%; M9BOR2000-T7-M1: 1\%; M9-SES1400-T2-M1: 1\%; M09-SES1400-T2M2: 1ㅇ M09-SES1400-T3-M2: 1 ㅇ M09-SES1400-T4-M2: 1\%; M9-SES2000-T2-M1: 1\%; M9-SES2000-T3-M1: 1\%; M9SES2000-T4-M1: 1\%; M9-SES2000-T5-M1: 1\%; M10-CAI1400-T1M1: 2क; M10-CAI2000-T2-M1: 1; M10-CAI2000-T4-M1: 1; M10-CAI2000-T5-M1: 107; M10-CAI2000-T6-M1: 1 웅 M10-CAI2000-T1-M2: 1\%; M10-CAI2000-T2-M2: 3; M10CAI1400-T3-M2: 2\%. Material deposited at MNHN, except for 10 ㅇ deposited at UB.

Distribution. - Species known from the Palaearctic region (FerrerSuay et al. 2012a). Previously cited from France by Kieffer (1902a: 10) and De Gaulle (1908: 26). 

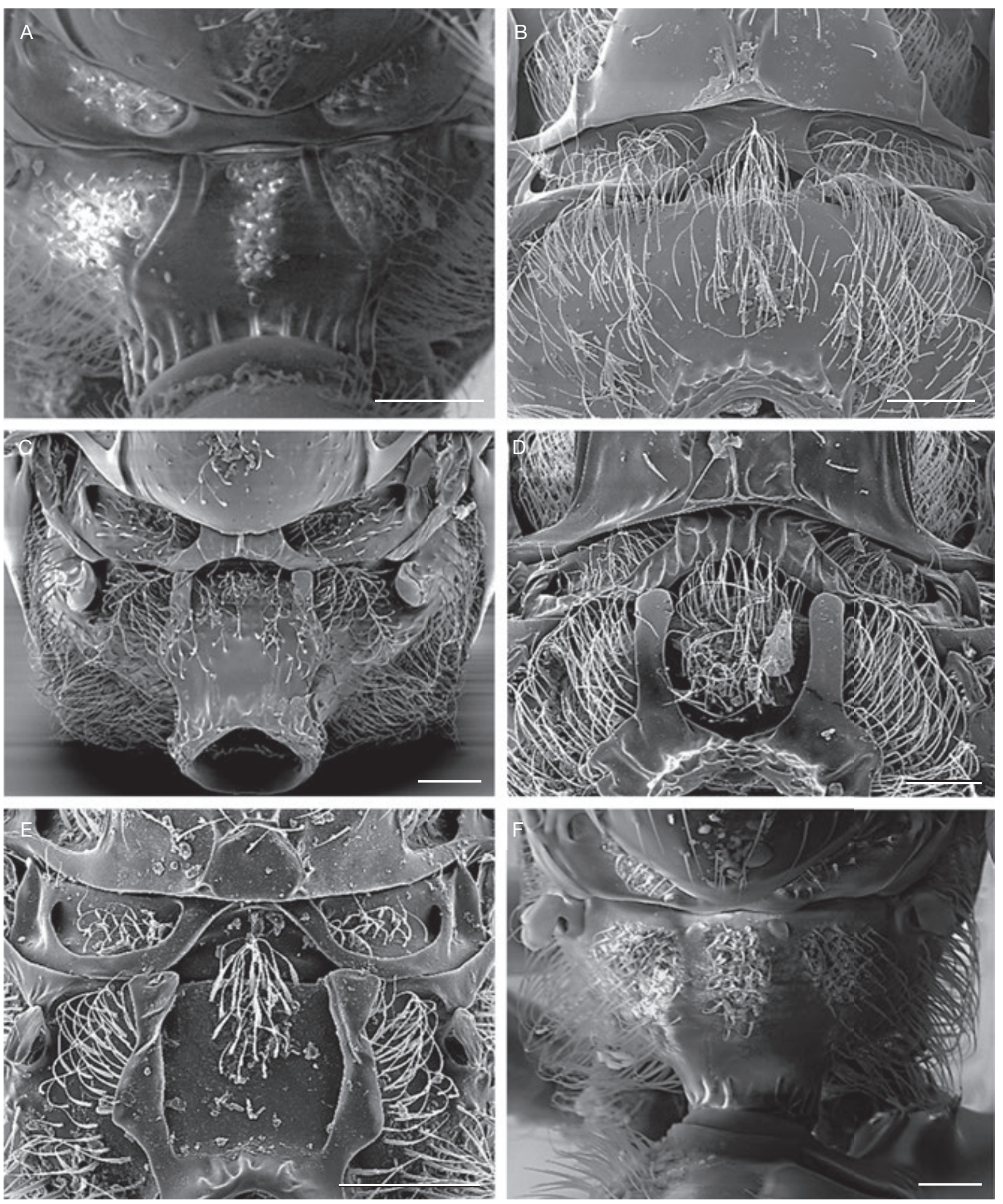

Fig. 6. - Types of propodea: A, A. arcuata (Kieffer, 1902); B, A. victrix (Westwood, 1833); C, P. villosa (Hartig, 1841); D, A. trapezoidea (Hartig, 1841); E, D. subclavata Förster, 1869; F, A. citripes (Thomson, 1862). Scale bars: $50 \mu \mathrm{m}$. 
Hosts. - See Charipinae Worldwide Catalogue (Ferrer-Suay et al., 2012a).

DiAGNOSIS. - Alloxysta macrophadna is characterized by: a large, partially open radial cell, $3.0 \times$ longer than wide (Fig. $3 \mathrm{~K}$ ), pronotal carinae present, propodeal carinae absent, female antenna with rhinaria beginning from F4, F1 longer than pedicel and F2, F2 shorter than F3, F3 shorter than F4 (Fig. 2K), male antenna with rhinaria beginning from F3, F2 and F3 clearly curved, F1 longer than pedicel and subequal to F2, F2 longer than F3, F3 longer than F4. Similar to Alloxysta obscurata (Hartig, 1840), but the two species can be differentiated by the shape of flagellomeres and their relative proportions: F1 subequal to F2, F2 longer than F3 and F3 subequal to $\mathrm{F} 4$ in $A$. macrophadna (Fig. $2 \mathrm{~K}$ ) while $\mathrm{F} 1$ longer than F2, F2 shorter than F3 and F3 shorter than F4 in $A$. obscurata (Fig. 2O); F2 and F3 strongly curved in $A$. macrophadna male, but without any curved flagellomere in A. obscurata male; proportions of radial cell $3.0 \times$ longer than wide in $A$. macrophadna (Fig. $3 \mathrm{~K}$ ), versus $2.7 \times$ in $A$. obscurata (Fig. $3 \mathrm{O}$ ).

\section{Alloxysta melanogaster (Hartig, 1840) \\ (Figs 2L; 3L)}

Xystus melanogaster Hartig, 1840: 200.

Material EXAMINED. - (7ㅇ). M09-SES1400 T2-M2, 30.VI-10. VII.2009: 19; M09-SES2000-T4-M1, 23.VII-07.VIII.2009: 29; M09-BOR1400-T2-M1, 24.VI-09.VII.2009: 1 $;$; M10-CAI1400-T7M1, 30.IX-15.X.2010: 2\%; M10-CAI2000-T3-M1, 31.VII-16. VIII.2010: 1․ Material deposited at MNHN, except for 3 아 deposited at UB.

Distribution. - Species known from the Palaearctic region (FerrerSuay et al. 2012a). Previously cited from France by De Gaulle (1908: 26) and Dalla Torre \& Kieffer (1910: 279).

Hosts. - See Charipinae Worldwide Catalogue (Ferrer-Suay et al. 2012a).

DiAGNOSIS. - Alloxysta melanogaster is characterized by: a partially open radial cell, $2.3 \times$ longer than wide (Fig. $3 \mathrm{~L}$ ), pronotal and propodeal carinae present, female antenna with rhinaria beginning from F3, F1 subequal to pedicel, F1 longer than F2, F2 subequal to F3, F4 longer than F3 (Fig. 2L), male antenna with rhinaria beginning from F2, F1 longer than pedicel and F2, F2-F4 subequal in length. Similar to A. longipennis, but the two species can be differentiated by the proportion between flagellomeres in female: pedicel-F3 subequal in $A$. melanogaster (Fig. $2 \mathrm{~L}$ ) while $\mathrm{F} 1$ longer than pedicel and F2, F2 subequal to F3 in A. longipennis (Fig. 2J); size of radial cell $2.3 \times$ longer than wide in $A$. melanogaster (Fig. 3L) but $2.6 \times$ in A. longipennis (Fig. 3J).

Alloxysta mullensis (Cameron, 1883)

(Figs 2M; 3M)

Allotria mullensis Cameron, 1883: 366.

MATERIAL EXAMINED. - (1 $0^{7} \&$ 21\%). M09-SES1400-T3-M2: 6\%; M09-SES1400-T6-M2: 19; M09-SES1400-T1-M2: 2 \%; M09-SES1400-T4-M2: 2ㅇ M09-SES2000-T3-M1: 3ㅇ M9SES2000-T6-M2: 1\%; M9-BOR2000-T4-M1: 1\%; M9-BOR1400 T3-M1: 1; M10-CAI2000 T1-M1: 1 \%; M10-CAI1400-T7-M2: $10^{7}$; M10-CAI1400 T4-M2: 1 ; M10-CAI1400 T7-M1: 1 ㅇ․ Material deposited at MNHN except for 10 \% deposited at UB.
Distribution. - Species previously known from the Palaearctic region (Ferrer-Suay et al. 2012b). First record from France.

Hosts. - See Charipinae Worldwide Catalogue (Ferrer-Suay et al. 2012a).

Diagnosis. - Alloxysta mullensis is characterized by: a closed radial cell, $2.2 \times$ longer than wide (Fig. $3 \mathrm{M}$ ), pronotal carinae absent, propodeal carinae present forming a plate, male and female with the rhinaria beginning from F4, F1 longer than F2, F2 subequal to F3, F3 shorter than F4 (Fig. 2M). Similar to $A$. fracticornis, but the two species can be differentiated by their antennae; ratio between F1 and pedicel: F1 subequal to pedicel in $A$. mullensis (Fig. 2M) while F1 longer than pedicel in $A$. fracticornis (Fig. $2 \mathrm{H}$ ); proportion between flagellomeres: $\mathrm{F} 1$ longer than $\mathrm{F} 2$ and $\mathrm{F} 2$ subequal to $\mathrm{F} 3$ in $A$. mullensis female (Fig. 2M) but F1-F3 subequal in length in $A$. fracticornis female (Fig. $2 \mathrm{H}$ ); without any flagellomere curved in A. mullensis male but with $\mathrm{F} 3$ curved in $A$. fracticornis male.

Alloxysta nigrita (Thomson, 1862)

(Figs 2N;3N)

Allotria nigrita Thomson, 1862: 409.

Material EXAmined. - (19). M9-BOR2000-T8-M2: 1 \% . Specimen deposited at MNHN.

Distribution. - Species known from the Palaearctic (Ferrer-Suay et al. 2012a). Previously cited from France by Kieffer (1902b: 44).

Hosts. - See Charipinae Worldwide Catalogue (Ferrer-Suay et al. 2012a).

Diagnosis. - Alloxysta nigrita is characterized by: a completely open radial cell, $2.9 \times$ longer than wide in both male and female (Fig. $3 \mathrm{~N}$ ), pronotal carinae present, propodeal carinae absent, female antenna with rhinaria beginning from $\mathrm{F} 4$ in both male and female, female antenna with F1 longer than pedicel and F2, F2 shorter than F3, F3 longer than F4 (Fig. 2N), male antenna with F1 longer than pedicel and subequal to F2, F2 longer or subequal to F3, F3 shorter than F4. Similar to A. brachycera, but the two species can be differentiated by the ratio between F2 and F3: F2 shorter than F3 in A. nigrita (Fig. $2 \mathrm{~N}$ ) while F2 longer than $\mathrm{F} 3$ in $A$. brachycera (Fig. 2C); proportions of radial cell $2.9 \times$ longer than wide in $A$. nigrita (Fig. $3 \mathrm{~N}$ ) but $2.7 \times$ in A. brachycera (Fig. 3C).

Alloxysta obscurata (Hartig, 1840)

(Figs 2O;3K)

Xystus obscuratus Hartig, 1840: 200.

MATERIAL EXAMINED. - (39). M9-BOR2000-T6-M1: 1 \%; M9BOR2000-T3-M1: 1; M9-BOR1400-T2-M1: 1 ㅇ. 2 우 deposited at MNHN and 1 o at UB.

Distribution. - Species known from Holarctic region (FerrerSuay et al. 2012a). Previously cited from France by Kieffer (1904: 597) and De Gaulle (1908: 26).

Hosts. - See Charipinae Worldwide Catalogue (Ferrer-Suay et al. 2012a). 


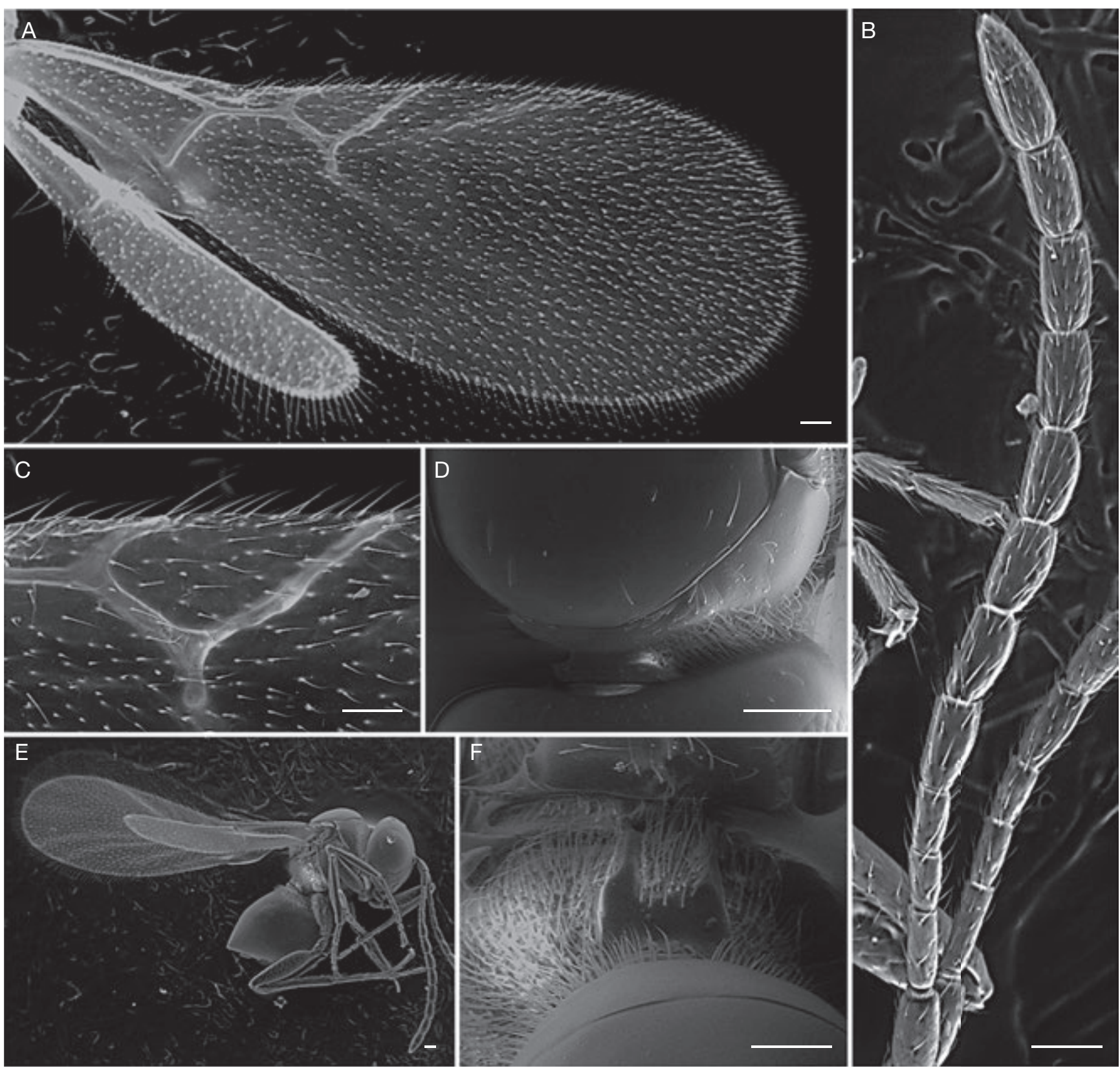

FIG. 7. - Alloxysta franca Ferrer-Suay \& Pujade-Villar, n. sp.: A, forewing; B, antenna; C, radial cell; D, pronotum; E, body; E, propodeum. Scale bars: 50 um.

DiAGNOSIS. - Alloxysta obscurata is characterized by: partially open radial cell, $2.7 \times$ longer than wide (Fig. 3O); pronotal carinae present, propodeal carinae absent; female antenna with rhinaria beginning from F3; F1 longer than pedicel and F2, F2 shorter than F3, F3 shorter than F4 (Fig. 2O); male antenna with rhinaria beginning from F4, F2 slightly curved, F1 longer than pedicel and F2, F2 longer than F3 and F3 longer than F4. Similar to $A$. macrophadna, but the two species can be differentiated by the shape and proportion between flagellomeres: F1 longer than $\mathrm{F} 2, \mathrm{~F} 2$ shorter than $\mathrm{F} 3$ and $\mathrm{F} 3$ shorter than F4 in A. obscurata (Fig. 2O), versus F1 subequal to F2, F2 longer than F3 and F3 subequal to $\mathrm{F} 4$ in $A$. macrophadna (Fig. $2 \mathrm{~K}$ ); male antenna without any curved flagellomere in $A$. obscurata but with F2 and F3 strongly curved in $A$. macrophadna; proportions of radial cell $2.7 \times$ longer than wide in $A$. obscurata (Fig. $3 \mathrm{O}$ ) but $3.0 \times$ in A. macrophadna (Fig. 3K).

\section{Alloxysta pilae}

Ferrer-Suay, n. sp.

(Fig. 8)

TYPE MATERIAL. - (19). Holotype. 9 deposited at MNHN, labelled M10-CAI1400-T6-M1, Saorge (06), Forêt de Caïros, fir forest, Alt: 1379, 15-30.IX.2010.

Etymology. - The new species is dedicated to the mother of the first author, to thank her for her constant support.

Distribution. — France.

Hosts. - Unknown. 
Diagnosis. - Alloxysta pilae Ferrer-Suay, n. sp. is characterized by: a completely open radial cell, $2.2 \times$ longer than wide; pronotal and propodeal carinae present; female antenna with rhinaria beginning from F4, F1 longer than F2, F2 subequal to F3, F3 shorter than F4. Similar to $A$. franca Ferrer-Suay \& Pujade-Villar, n. sp., but the two species can be differentiated by the pronotal carinae: present in A. pilae Ferrer-Suay, n. sp., versus absent in $A$. franca Ferrer-Suay $\&$ Pujade-Villar, n. sp.; proportions of radial cell $2.2 \times$ longer than wide in $A$. pilae Ferrer-Suay, n. sp., versus $2.4 \times$ in $A$. franca Ferrer-Suay \& Pujade-Villar, n. sp.

\section{DESCRIPTION}

Length

Female: $0.9 \mathrm{~mm}$. Male unknown.

\section{Coloration}

Head, mesosoma and metasoma yellowish brown. Scape, pedicel, F1-F3 dark yellow, F4-F11 yellowish brown. Legs yellow and wing venation yellowish brown.

\section{Head}

Transversely ovate, smooth and shiny, slightly wider than high in front view. Vertex glabrous, face hairy. Setae present below, between and a few above toruli. Transfacial line $1.1 \times$ height of compound eye. Malar space $0.6 \times$ height of compound eye.

\section{Antenna}

Female: 13-segmented, filiform. All flagellomeres sparsely setose. F1-F3 smooth and thinner than remaining flagellomeres; F4-F11 club shaped and with rhinaria. Antennal formula: 2.5 (1.5); 3.1 (0.9); 2.5 (0.9); 2.5 (0.9); 3.4 (1.3) (Fig. 8D).

\section{Mesosoma}

Pronotum sparsely setose, with two thick latero-median carinae (Fig. 8C). Mesoscutum smooth and shiny, rounded in dorsal view, with few scattered setae, and two setiferous lines on both sides. Scutellum smooth and shiny, with scattered setae more abundant at scutellum apex. Height of mesopleural triangle along anterior margin $1.4 \times$ the height of mesopleuron. Propodeum densely setose; with two carinae present forming a plate with lateral sides slightly curved and few setae antero-medially (Fig. 8F).

\section{Forewing}

Longer than body, $1.6 \times$ longer than mesosoma and metasoma together; covered with dense pubescence; marginal setae present (Fig. 8A). Open radial cell $2.2 \times$ longer than wide (Fig. 8B). R1 short and slightly curved; Rs long and slightly curved.

\section{Metasoma}

Proximal part with an incomplete ring of setae, glabrous medially and wider laterally. Rest of metasoma smooth and shiny with terga clearly visible.
Alloxysta pilipennis (Hartig, 1840)

(Figs 2P; 3P)

Xystus pilipennis Hartig, 1840: 199.

Material EXAMINED. - (8\%). M9-BOR1400-T2-M1: 19; M9-BOR1400 T1-M2: 1 \% M09-SES1400-T1-M2: 39; M9SES1400-T2-M2: 2\%; M10-CAI2000-T2-M1: $19.4 \%$ deposited at MNHN and $4 \%$ at UB.

Distribution. - Previously known from the Palaearctic (FerrerSuay et al. 2012a). First record from France.

Hosts. - See Charipinae Worldwide Catalogue (Ferrer-Suay et al. 2012a).

DiAGNOSIS. - Alloxysta pilipennis is characterized by: a closed radial cell, $2.5 \times$ longer than wide (Fig. 3P); pronotal and propodeal carinae present; female antenna with rhinaria beginning from $\mathrm{F} 3$, F1 longer than pedicel and F2, F2-F4 subequal in length (Fig. 2P). Male unknown. Similar to Alloxysta pusilla (Kieffer, 1902), but the two species can be differentiated by the proportion between flagellomeres: $\mathrm{F} 2$ subequal to $\mathrm{F} 3$ in $A$. pilipennis female (Fig. $2 \mathrm{P}$ ), versus F2 shorter than F3 in $A$. pusilla female (Fig. 2S); F1-F3 distinctly unequal and without any curved flagellomere in A. pilipennis male, as opposed to F1-F3 subequal in length and with slightly curved flagellomere in $A$. pusilla male; proportions of radial cell $2.4 \times$ longer than wide in $A$. pilipennis female (Fig. 3P), versus $2.7 \times$ in $A$. pusilla female (Fig. 3S).

Alloxysta postica (Hartig, 1841)

(Figs 2Q; 3Q)

Xystus posticus Hartig, 1841: 352.

Material eXAmined. - (9\%). M9-BOR1400-T1-M1: 19 ; M9-BOR1400-T2-M1: 1 \% : M9-BOR1400-T4-M1: 1 ; ; M9SES1400-T2-M2: 1\%; M9-SES1400-T3-M2: 1\%; M9-SES1400-T6M2: 1; M9-SES2000-T3-M1: 1ㅇ M10-CAI1400-T6-M2: 1웅 M10-CAI2000-T7-M2: 19.5 웅 deposited at MNHN and $5 \circ$ at UB.

Distribution. - Species previously known from the Palaearctic region (Ferrer-Suay et al. 2012a). First record from France.

Hosts. - See Charipinae Worldwide Catalogue (Ferrer-Suay et al. 2012a).

DiAGNOSIS. - Alloxysta postica is characterized by: a partially open radial cell, $2.5 \times$ longer than wide (Fig. 3Q); pronotal carinae and propodeal carinae present; female antenna with rhinaria beginning from F4, pedicel-F4 subequal in length (Fig. 2Q). Male unknown. Similar to $A$. citripes, but the two species can be differentiated by the shape of propodeal carinae: clearly visible and forming a plate in $A$. postica, whereas the carinae are not protruding in $A$. citripes (Fig. 6F); proportions of radial cell $2.5 \times$ longer than wide in $A$. postica (Fig. 3Q) but $2.1 \times$ in A. citripes (Fig. 3G).

Alloxysta proxima Belizin, 1962

(Figs 2R; 3R)

Alloxysta proxima Belizin, 1962: 128.

Material EXAMINED. - (7\%). M9-BOR2000-T5-M2: $1 \%$; M9SES2000-T2-M1: 1\%; M9-SES2000-T5-M1: 1\%; M09-SES2000-T3M2: 1\%; M09-SES2000-T6-M2: 1 $\%$; M10-CAI2000-T1-M1:1 ;

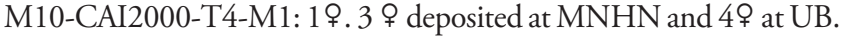



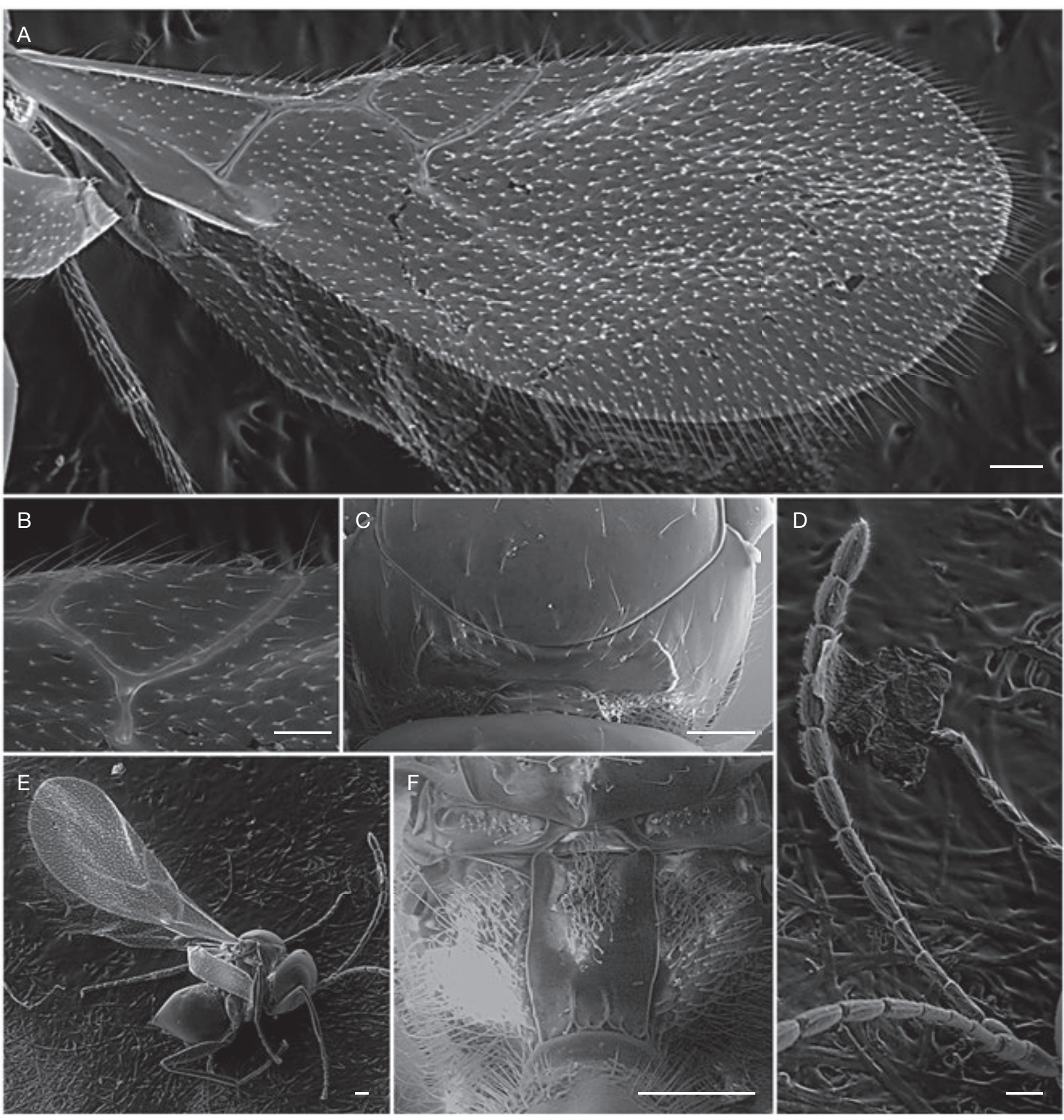

FIG. 8. - Alloxysta pilae Ferrer-Suay, n. sp.: A, forewing; B, radial cell; C, pronotum; D, antennae; E, body; F, propodeum. Scale bars: 50 um.

Distribution. - Species previously known from the Palaearctic (Ferrer-Suay et al. 2012a). First record from France.

HosTs. - Unknown.

DiAGNOSIS. - Alloxysta proxima is characterized by: a completely open radial cell, $2.3 \times$ longer than wide (Fig. $3 \mathrm{R}$ ); pronotal carinae and propodeal carinae absent; female antenna with rhinaria beginning from F4, F1 longer than pedicel, F2 longer than F1, F2 longer than F3, F3 subequal to F4 (Fig. 2R). Male unknown. This combination of features is not known in any other species of Alloxysta.
Alloxysta pusilla (Kieffer, 1902)

(Figs 2S; 3S)

Allotria (Allotria) pusilla Kieffer, 1902a: 13.

MATERIAL EXAMINED. - (19). M9-SES1400 T2-M2: 1․ Deposited at MNHN.

Distribution. - Species known from the Palaearctic (Ferrer-Suay et al. 2012a). Previously cited from France by Kieffer (1902a: 13) and De Gaulle (1908: 26). 

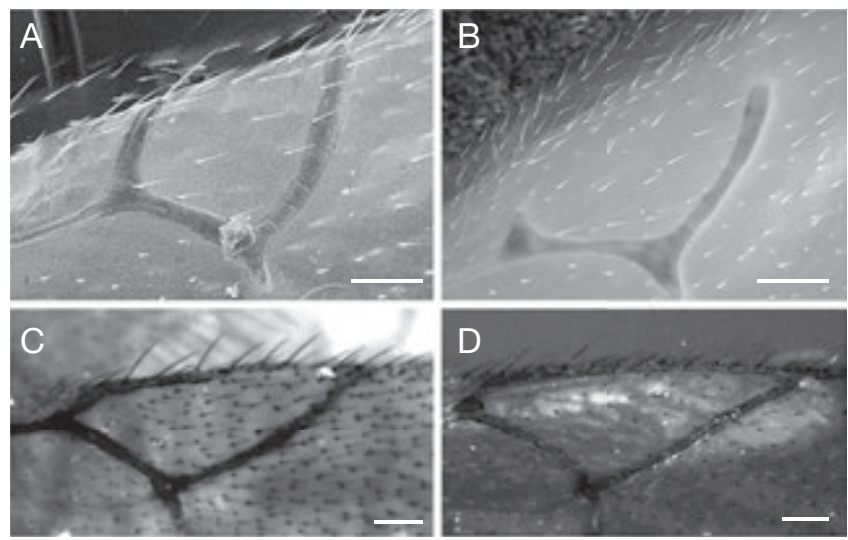

FIG. 9. - Types of radial cells: A, A. trapezoidea (Hartig, 1841); B, D. subclavata Förster, 1869; C, P. villosa (Hartig, 1841); D, P. americana Baker, 1896. Scale bar: $50 \mu \mathrm{m}$.

Hosts. - See Charipinae Worldwide Catalogue (Ferrer-Suay et al. 2012a).

DiAgNOSIs. - Alloxysta pusilla is characterized by: a closed radial cell, $2.7 \times$ longer than wide in female (Fig. $3 S$ ) and $2.4 \times$ in male, pronotal and propodeal carinae present, forming a plate; female antenna with rhinaria beginning from F3, F1 longer than pedicel and F2, F2 shorter than F3, and F3 shorter than F4 (Fig. 2S); male antenna with rhinaria beginning from F1, pedicel-F3 subequal in length, F4 longer than F3, F1-F3 slightly curved. Similar to $A$. pilipennis, but the two species can be differentiated by the proportions between flagellomeres in both male and female: F2 shorter than F3 in A. pusilla female (Fig. $2 S$ ), versus F2 subequal to F3 in A. pilipennis female (Fig. 2P); F1-F3 subequal in length and slightly curved in $A$. pusilla male, versus F1-F3 distinctly unequal and with all flagellomers uncurved in $A$. pilipennis male; proportions of radial cell $2.7 \times$ longer than wide in A. pusilla female (Fig. $3 \mathrm{~S}$ ), versus $2.4 \times$ in $A$. pilipennis female (Fig. $3 \mathrm{P}$ ).

\section{Alloxysta victrix (Westwood, 1833)} (Figs 2T; 3T; 6B)

Allotria victrix Westwood, 1833: 495.

Material EXAMINED. - (1 $0^{7} \& 31$ \% $)$. M9-SES1400-T2-M2: 6\%; M9-SES1400-T4-M2: 1\%; M9-SES1400-M2-TT3: 2\%; M9-SES2000-T5-M1: 1; M9-SES2000-T4-M1,: 2ㅇ M9SES2000-T2-M1: $1 \%$; M9-SES2000-T3-M1: 2\%; M9-BOR1400-T3M1: 1ㅇ M9-BOR1400-T2-M1: 3ㅇ M9-BOR1400-T4-M1: $10^{7} \&$ 1\%; M9-BOR1400-T2-M2: 1 \%; M9-BOR2000-T6-M1: 1 ; M9-BOR2000-T3-M1: 2\%; M9-BOR2000-T4-M1: $1 \%$; M10-CAI2000-T1-M1: 1\%; M10-CAI2000-T4-M1: 1\%; M10CAI2000-T2-M1: 2\%; M10-CAI1400-T1-M2: 2\%. Material deposited at MNHN, except for $15 \%$ deposited at UB.

Distribution. - Cosmopolitan (Ferrer-Suay et al. 2012a). Previously cited from France by Kieffer (1902a: 15, 16; 1902b: 70; 1904: 600) and De Gaulle (1908: 26).

Hosts. - See Charipinae Worldwide Catalogue (Ferrer-Suay et al. 2012a).

DiAGNOSIS. - Alloxysta victrix is characterized by: a large closed radial cell, $3.0 \times$ longer than wide (Fig. $3 \mathrm{~T})$; pronotal carinae present, propodeum without carinae and lacking setae on longitudinal areas bearing propodeal carinae in other Charipinae species (Fig. 6B), male and female with rhinaria beginning from F3, F1 longer than pedicel and F2, F2-F4 subequal (Fig. 2T), F1-F3 curved in male. Similar to A consobrina, but the two species can be differentiated by the proportions between flagellomeres: F2-F4 subequal in length in A. victrix (Fig. $2 \mathrm{~T}$ ), versus $\mathrm{F} 2$ subequal to $\mathrm{F} 3$ and $\mathrm{F} 3$ shorter than F4 in A. consobrina (Fig. 2I); proportions of radial cell $3.0 \times$ longer than wide in $A$. victrix (Fig. 3T), versus $2.7 \times$ in $A$. consobrina (Fig. 2T); and the propodeal pubescence: with two longitudinal glabrous areas in $A$. victrix, as opposed to entirely and densely setose in $A$. consobrina the propodeum.

\section{Genus Apocharips Fergusson, 1986}

Apocharips trapezoidea (Hartig, 1841) (Figs 6D; 9A; 10A)

Xystus trapezoideus Hartig, 1841: 352.

MATERIAL EXAMINED. - (10 $\left.0^{7}\right)$. M9-SES2000 T4-M1: $10^{7}$. Deposited at MNHN.

Distribution. - Previously known from the Palaearctic region (Ferrer-Suay et al. 2012a). First record from France. Currently the only species of Apocharips known from the Mediterranean Alps.

Hosts. - See Charipinae Worldwide Catalogue (Ferrer-Suay et al. 2012a).

DiAGNOSIS. - Apocharips trapezoidea is mainly characterized by: a completely open radial cell, 1.0 times as long as wide (Fig. 9A); pronotal and propodeal carinae present (Fig. 6D); apex of scutellum with $\mathrm{M}$-shaped carinae; female antenna with rhinaria beginning from F5, F1 longer than pedicel and F2, F2 subequal to F3, F3 shorter than F4 (Fig. 10A); male antenna with rhinaria beginning from F1, F1 longer than pedicel and F2, F2-F4 subequal in length. It is easily differentiated from the other Apocharips species by its radial cell completely open with parallel $\mathrm{R} 1$ and Rs veins (Fig. 9A). The most similar Apocharips species is Apocharips hansoni Menke, 1993, but they can be readily separated by the presence of radial carinae around the clypeus in $A$. hansoni, which are lacking in A. trapezoidea.

Genus Dilyta Förster, 1869

Dilyta subclavata Förster, 1869 (Figs 9B; 10B)

Dilyta subclavata Förster, 1869: 338.

MATERIAL EXAMINED. - (10 \& 2\%). M09-BOR1400-T6-M1: 1\%; M09-SES1400-T2-M2: $10^{7}$; M10-CAI1400-T2-M1: 1․ Material deposited at MNHN, except for 19 deposited at UB.

Distribution. - Known from Palaearctic region (Ferrer-Suay et al. 2012a). Previously cited from France by De Gaulle (1908: 26) and Dalla Torre \& Kieffer (1910: 255). Currently the only species of Dilyta genus present in the Mediterranean Alps.

Hosts. - See Charipinae Worldwide Catalogue (Ferrer-Suay et al. 2012a).

DiAgNOSIS. - Dilyta subclavata is mainly characterized by: a completely open radial cell, $1.8 \times$ longer than wide $($ Fig. 9B); pronotum and propodeal carinae present; apex of scutellum with $n$-shaped carina; female antenna with rhinaria beginning from F6, F1 slightly shorter or subequal to pedicel, F2 subequal to F3, F4 longer than F3 (Fig. 10B); male antenna with rhinaria beginning from F4, F1 slightly 

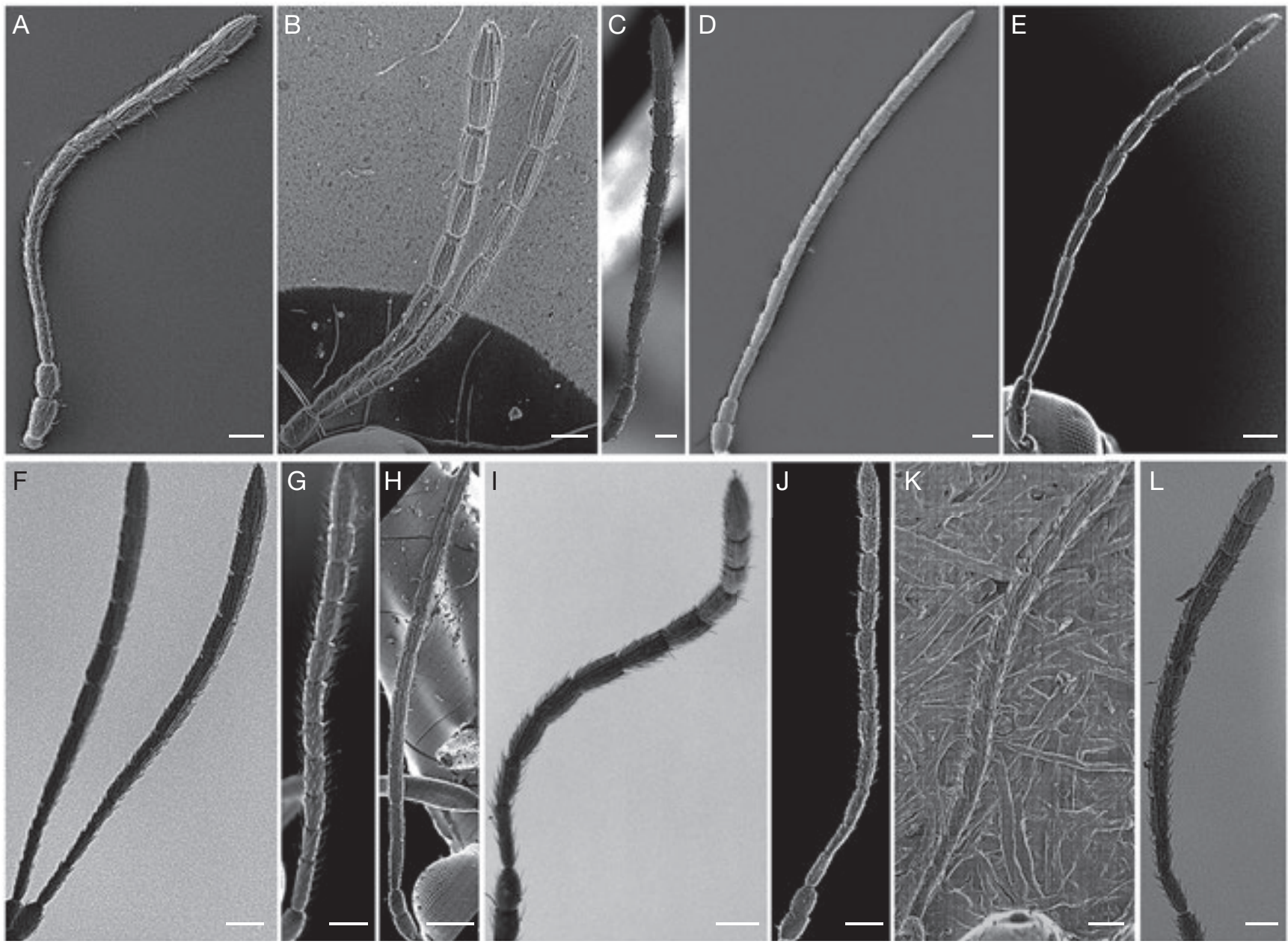

FIG. 10. - Types of antennae: A, A. trapezoidea (Hartig, 1841); B, D. subclavata Förster, 1869; C, P. abbreviata (Thomson, 1877); D, P. americana Baker, 1896; E, P. calverti Andrews, 1978; F, P. evenhuisi Pujade-Villar \& Paretas-Martínez, 2006; G, P. gutierrezi Andrews, 1978; H, P. longicornis (Hartig, 1840); I, P. stenos Andrews, 1978; J, P. villosa (Hartig, 1841); K, P. salicis (Cameron, 1883); L, P. fuscicornis (Thomson, 1877). Scale bars: $50 \mu \mathrm{m}$.

longer than pedicel, sometimes slightly arched, F2 shorter than F1 and F3, F3 shorter than F1, F1 subequal to F4. This species is easily differentiated from the other Dilyta species by the punctuation present on the distal part of its metasoma, F1 slightly shorter or subequal to pedicel, F2 subequal to F3, and F4 longer than F3 (Fig. 10B).

Genus Phaenoglyphis Förster, 1869

\section{Phaenoglyphis abbreviata}

(Thomson, 1877) (10C)

Allotria (Auloxysta) abbreviata Thomson, 1877: 812.

MATERIAL EXAMINED. - (19). M09-SES1400-T3-M1: 1\%. Deposited at MNHN.

Distribution. - Previously known from the Palaearctic region (Ferrer-Suay et al. 2012a). First record from France.

Hosts. - See Charipinae Worldwide Catalogue (Ferrer-Suay et al. 2012a).

Diagnosis. - Phaenoglyphis abbreviata is characterized by: a closed radial cell, $2.5 \times$ longer than wide; pronotal and propodeal carinae present; notauli present and rounded; scutellar foveae separated by a small and well defined carina; female antenna with rhinaria beginning from F3, F1 subequal to pedicel, F1 longer than F2, F2 shorter than F3, F3 subequal to F4 (Fig. 10C). It is similar to Phaenoglyphis moldavica Ionescu, 1969, but the two species can be differentiated by the proportions between flagellomeres: F1 longer than F2, F2 shorter than F3 in P. abbreviata, versus F1-F3 subequal in length in P. moldavica; shape of scutellar foveae: small, rounded and separated by a wide carina in P. abbreviata, but large and separated by a fine carina in $P$. moldavica.

\section{Phaenoglyphis americana Baker, 1896}

(Fig. 9D; 10D)

Phaenoglyphis americana Baker, 1896: 131.

MATERIAL EXAMINED. - (2ㅇ). M09-SES2000-T4-M1: 1; M09SES2000-T6-M2: 1 \% 1 deposited at MNHN and $1 \%$ at UB.

Distribution. - Previously known from the Nearctic and Neotropical regions (Ferrer-Suay et al. 2012a). First record from France.

HosTs. - See Charipinae Worldwide Catalogue (Ferrer-Suay et al. 2012a). 
Diagnosis. - Phaenoglyphis americana is characterized by: a closed radial cell, $2.8 \times$ longer than wide (Fig. 9D); pronotal and propodeal carinae present; notauli present, scutellum with two rounded foveae separated by a carina and open basally; female antenna with rhinaria beginning from F1, flagellum thickened from F2, F1 longer than pedicel, F1-F4 subequal in length, width and shape (Fig. 10D); male antenna with rhinaria and flagellum thickening beginning from F2, F1 curved, longer than pedicel and F2, F2 shorter than F3. Similar to Phaenoglyphis fuscicornis (Thomson, 1877), but the two species can be differentiated by: the thickening of flagellum from F2 in P. americana female (Fig. 10D), as opposed to from F3 in P. fuscicornis (Fig. 10L); the shape of notauli: clearly marked along their entire length in $P$. americana, versus deeply marked anteriorly and weakly posteriorly in $P$. fuscicornis; presence of rhinaria and thickening of flagellum in male: both beginning from F2 in P. americana, whereas the thickening begins from $\mathrm{F} 3$ and the rhinaria from $\mathrm{F} 5$ in $P$. fuscicornis.

\section{Phaenoglyphis calverti Andrews, 1978} (Fig. 10E)

\section{Phaenoglyphis calverti Andrews, 1978: 37}

MATERIAL EXAMINED. - (19). M09-SES1400-T6-M2: 1․ Deposited at MNHN.

Distribution. - Previously known from the Nearctic region (Ferrer-Suay et al. 2012a). First record from France.

Hosts. - See Charipinae Worldwide Catalogue (Ferrer-Suay et al. 2012a)

DiAGNOSIS. - Phaenoglyphis calverti is characterized by: a closed radial cell, $2.7 \times$ longer than wide; pronotal and propodeal carinae present; notauli absent; scutellar foveae rounded, separated by a carina and open basally; female antenna with rhinaria beginning from F3, F1 longer than pedicel and F2, F2 shorter than F3, F3 subequal to F4 (Fig. 10E); male antenna with rhinaria beginning from F3, F1 curved; F1 longer than pedicel and F2, F2 slightly shorter than F3. Similar to Phaenoglyphis insularis (Belizin, 1973), but the two species can be differentiated by the ratio between F2/F3: F2 shorter than F3 in P. calverti, versus F2 longer than F3 in P. insularis; shape of propodeal carinae: slightly curved in $P$. calverti, but straight in $P$. insularis; shape of mesoscutum: flat in $P$. calverti, versus very gibbous in P. insularis.

\section{Phaenoglyphis evenhuisi \\ Pujade-Villar \& Paretas-Martínez, 2006}

(Fig. 10F)

Phaenoglyphis evenhuisi Pujade-Villar \& Paretas-Martínez, 2006: 479.

MATERIAL EXAMINED. - (1ㅇ). M09-BOR1400-T2-M1: 1ㅇ․ Deposited at MNHN.

Distribution. - Previously known from the Palaearctic region (Ferrer-Suay et al. 2012a). First record from France.

Hosts. - Unknown.

DiAGNOSIS. - Phaenoglyphis evenhuisi is characterized by: a closed radial cell, $3.0 \times$ longer than wide; pronotal and propodeal carinae present; notauli barely distinct; scutellar foveae oval, well-defined and separated by a carina, each fovea has an internal carina at its posterior margin; female antenna with rhinaria beginning from F4, F1 slightly longer or subequal to pedicel, F1 longer than F2, F2 subequal to F3 and F3 shorter than F4 (Fig. 10F). Phaenoglyphis evenhuisi is easily distinguished from the other Phaenoglyphis species present in the Mediterranean Alps because it is the only species whose pronotum and mesoscutum are not smooth but entirely covered by a fine reticulate sculpture.

\section{Phaenoglyphis fuscicornis (Thomson, 1877)}

(Fig. 10L)

Allotria (Auloxysta) fuscicornis Thomson, 1877: 813.

MATERIAl EXAMINED. - (19). M09-SES1400-T3-M1: 1․ Deposited at MNHN.

Distribution. - Previously known from the Palaearctic region (Ferrer-Suay et al. 2012a). First record from France.

HosTs. - Unknown.

Diagnosis. - Phaenoglyphis fuscicornis is characterized by: a closed radial cell, $2.8 \times$ longer than wide in both male and female; pronotal and propodeal carinae present; notauli present, scutellum with two oval scutellar foveae separated by a carina and not delimited basally; female antenna thickened from F3 and with rhinaria beginning from F1, F1 longer than pedicel, F1 slightly longer than F2, F2 slightly shorter than F3, F3 subequal to F4 (Fig. 10L), male antenna thickened from $\mathrm{F} 3$ and rhinaria beginning from F5, F1 curved, F1 longer than pedicel and F2, F2 subequal to F3, F3 slightly shorter than F4. Similar to $P$. americana, but the two species can be differentiated by: the thickening of female flagellum beginning from F3 in $P$. fuscicornis (Fig. 10L) and from F2 in P. americana (Fig. 10D); shape of notauli: deeply excavated anteriorly and weakly posteriorly in P.fuscicornis, as opposed to clearly marked along their entire length in P. americana; presence of rhinaria and flagellum thickening in male: thickening begins from F3 and rhinaria from F5 in P. fuscicornis, whereas both begin from F2 in P. americana.

\section{Phaenoglyphis gutierrezi Andrews, 1978} (Fig. 10G)

Phaenoglyphis gutierrezi Andrews, 1978: 39.

MATERIAL EXAMINED. - (19). M09-BOR2000-T5-M2: 1ㅇ․ Deposited at MNHN.

Distribution. - Previously known from Nearctic region (FerrerSuay et al. 2012a). First record from France and from the Palaearctic. Faunistic studies have led to significant increases in the known distribution range of some species of Charipinae, including many cases of Palaearctic species being found in the Nearctic region (Ferrer-Suay et al., 2014). Thus all the above studies largely increase the distribution range of some species (with the remaining problem of cryptic species which could be solved with molecular studies).

Hosts. - Unknown.

DiAGNOSIS. - Phaenoglyphis gutierrezi is characterized by: a closed radial cell, $2.8 \times$ longer than wide; pronotal and propodeal carinae present; notauli present; scutellar foveae oval, separated by a carina and not delimited basally; female antenna with rhinaria beginning from F3, F1 longer than pedicel and F2, F2-F4 subequal in length (Fig. 10G). Similar to Phaenoglyphis salicis (Cameron, 1883), but the two species can be differentiated by the ratios between flagellomeres: F2-F4 subequal in length in P. gutierrezi (Fig. 10G), versus F2 shorter than F3, F3-F4 subequal in length in P. salicis (Fig. 10K); shape of scutellar foveae: slightly open basally in $P$. gutierrezi but completely defined and with two apical lines in $P$. salicis. 

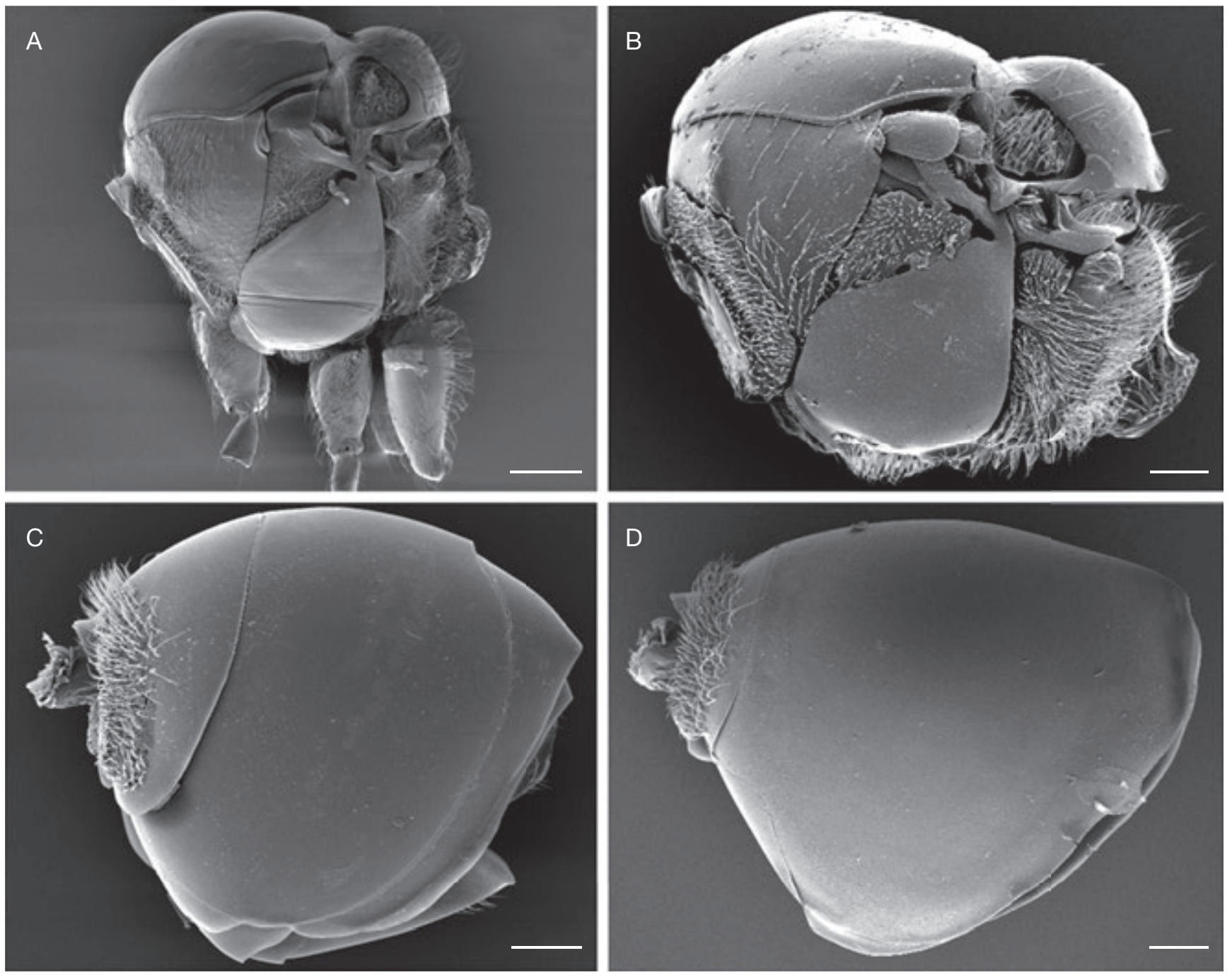

FIG. 11. - Types of mesopleura and metasomae: A, Phaenoglyphis Förster, 1869 sp.; B, C, Alloxysta Förster, 1869 sp.; D, Apocharips Fergusson, 1986 sp. Scale bars: $50 \mu \mathrm{m}$.

Phaenoglyphis longicornis (Hartig, 1840)

(Fig. 10H)

Xystus longicornis Hartig, 1840: 199.

MATERIAL EXAMINED. - (3ㅇ). M09-SES1400-T2-M2: 1 ; SES2000-T5-M1: 1; M09-BOR1400-T3-M1: 1 ․ 2 ㅇ deposited at MNHN and 19 at UB.

Distribution. - Previously known from the Palaearctic region (Ferrer-Suay et al. 2012a). First record from France.

Hosts. - Unknown.

DiAGNOSIS. - Phaenoglyhis longicornis is characterized by: a closed radial cell, $2.7 \times$ longer than wide; pronotal, propodeal carinae and notauli present; oval scutellar foveae with straight lateral margins, separated by a carina and not delimited basally; female antenna with rhinaria beginning from F1, F1 longer than pedicel and F2, F2 subequal to F3 and F3 shorter than F4 (Fig. 10H). Similar to Phaenoglyphis stricta (Thomson, 1877), but the two species can be differentiated by the beginning of rhinaria: from the base of F1 in $P$. longicornis and from the second quarter of F1 in P. stricta; shape of scutellar foveae: not delimited basally in P. longicornis, whereas in $P$. stricta they are not delimited apically and basally; proportions of radial cell $2.7 \times$ longer than wide in P. longicornis, versus $2.4 \times$ in P. stricta.

Phaenoglyphis salicis (Cameron, 1883)

(Fig. 10K)

Allotria salicis Cameron, 1883: 367.

Material eXamined. - (19). M09-SES2000-T6-M2: 19. Deposited at MNHN.

Distribution. - Previously known from Palaearctic region (FerrerSuay et al. 2012a). First record from France.

Hosts. - See Charipinae Worldwide Catalogue (Ferrer-Suay et al. 2012a).

DiagnOSIs. - Phaenoglyphis salicis is characterized by: a closed radial cell, $2.5 \times$ longer than wide; pronotal and propodeal carinae present; notauli barely distinct; scutellar foveae oval, completely defined and 
TABLE 3. - List of the 35 Charipinae Dalla Torre \& Kieffer, 1910 species recorded in the Mercantour National Park. Besides the newly described species, those followed by an asterisk are additions to the French fauna.

\begin{tabular}{l}
\hline Alloxysta \\
\hline abdera* Fergusson, 1986 \\
alpina Ferrer-Suay \& Pujade-Villar, n. sp. \\
arcuata* (Kieffer, 1902) \\
brachycera* Hellén, 1963 \\
brevis* (Thomson, 1962) \\
castanea (Hartig, 1841) \\
circumscripta (Hartig, 1841) \\
citripes (Thomson, 1862) \\
consobrina (Zetterstedt, 1838) \\
fracticornis* (Thomson, 1862) \\
franca Ferrer-Suay \& Pujade-Villar, n. sp. \\
longipennis* (Hartig, 1841) \\
macrophadna (Hartig, 1841) \\
melanogaster (Hartig, 1840) \\
mullensis* (Cameron, 1883) \\
nigrita (Thomson, 1862) \\
obscurata (Hartig, 1840) \\
pilae Ferrer-Suay, n. sp. \\
pilipennis* (Hartig, 1840) \\
postica* (Hartig, 1841) \\
proxima* Belizin, 1962 \\
pusilla (Kieffer, 1902) \\
victrix (Westwood, 1833) \\
\hline Apocharips \\
\hline trapezoidea* (Hartig, 1841) \\
\hline Dilyta \\
\hline subclavata Förster, 1869 \\
\hline Phaenoglyphis \\
abbreviata* (Thomson, 1877) \\
americana* Baker, 1896 \\
calverti* Andrews, 1978 \\
evenhuisi* Pujade-Villar \& Paretas-Martínez, 2006 \\
fuscicornis* (Thomson, 1877) \\
gutierrezi* Andrews, 1978 \\
longicornis* (Hartig, 1840) \\
salicis* (Cameron, 1883) \\
\hline
\end{tabular}

with two apical lines; female antenna with rhinaria beginning from F3, F1 longer than pedicel and F2, F2 shorter than F3, F3 subequal to F4 (Fig. 10K). Similar to P. gutierrrezi, from which it can be separated by the characters noted in the diagnosis of the latter.

\section{Phaenoglyphis stenos Andrews, 1978}

(Fig. 10I)

Phaenoglyphis stenos Andrews, 1978: 43.

MATERIAL EXAMINED. - (19). M09-SES1400-T6-M2: 1․ Deposited at MNHN.

Distribution. - Previously known from the Nearctic and Neotropical regions (Ferrer-Suay et al. 2012a). First record from France.

Hosts. - See Charipinae Worldwide Catalogue (Ferrer-Suay et al. 2012a).

Diagnosis. - Phaenoglyphis stenos is characterized by: a closed radial cell, $2.9 \times$ longer than wide; pronotal and propodeal carinae present; notauli present, scutellum with two rounded foveae slightly fused medially and open basally; female antenna with rhinaria begin- ning from F2, F1 longer than pedicel and F2, F2 subequal to F3, F3 shorter than F4 (Fig. 10I). Similar to Phaenoglyphis heterocera (Hartig, 1841), but the two species can be differentiated by the antennae with rhinaria beginning from $\mathrm{F} 2$ in $P$. stenos, as opposed to from F3 in $P$. heterocera; ratio of pedicel/F1 in female: F1 longer than pedicel in $P$. stenos, but shorter than pedicel in $P$. heterocera; shape of propodeal carinae: slightly curved in $P$. stenos, versus straight in $P$. heterocera; proportions of radial cell $2.9 \times$ longer than wide in $P$. stenos, versus $2.7 \times$ in $P$. heterocera.

Phaenoglyphis villosa (Hartig, 1841)

(Figs 6C; 9C; 10J)

Xystus villosus Hartig, 1841: 353.

MATERIAL EXAMINED. - (1 $0^{7} \& 4$ 4 $)$. M09-SES1400-T6-M2: 19; M09-SES2000-T4-M1: $10^{7} \&$ 1 9 ; M09-BOR2000-T4-M1: 1 ; M10-CAI2000-T3-M1: 1 우. Material deposited at MNHN, except for 2 o deposited at UB.

Distribution. - Cosmopolitan (Ferrer-Suay et al. 2012a). Previously cited from France by Kieffer (1902a: 11, 12, 13; 1904a: 595, 597) and De Gaulle (1908: 26).

Hosts. - See Charipinae Worldwide Catalogue (Ferrer-Suay et al. 2012a).

DiAGNOSIS. - Phaenoglyphis villosa is characterized by: a partially open radial cell, 2.1-2.7 $\times$ longer than wide (Fig. 9C); pronotal (Fig. 6C) and propodeal carinae present (Fig. 6C); notauli absent, scutellum with two deep oval foveae more or less separated by a carina or completely fused; female antenna with rhinaria beginning from F3, F1 as long as pedicel or slightly longer, F1 subequal to F2, F2 shorter than F3, F3 shorter than F4 (Fig. 10J); male antenna with rhinaria beginning from F3, F1 subequal to F2, F2 shorter than F3. At the moment $P$. villosa is easily differentiated from the other Phaenoglyphis species because it is the only one having a partially open radial cell.

\section{DISCUSSION}

As aphid hyperparasitoids, Charipinae can have a significant economic impact, hence the importance of improving our knowledge of this group. Our studies of the Charipinae type material and their fauna from different parts of the world (Ferrer-Suay et al. 2012, 2013) has been very useful to determine the real limits between species and better know which are the most common, especially in Europe.

In addition to the three new species described here, the study of Charipinae from the Mercantour National Park led to add to the French fauna 19 other species. While most of them were already known from the Palearctic or Holarctic regions, four have been previously recorded only in the Nearctic region (Phaenoglyphis gutierrezi and P. calverti) or in the Nearctic and Neotropical regions (P. americana and P. stenos) (Table 3).

It is thus imperative to continue the study of Charipinae from different areas of the world, especially the most poorly studied areas, such as Africa, Australia and the Oriental regions. Large field samplings performed during the course of All Taxa Biodiversity Inventories like that of the Mercantour National Park provide a good opportunity to collect small, poorly studied taxa and thus contribute to reduce the shortfall in their taxonomy. 


\section{Key to the Charipinae Dalla Torre \& KiefFer, 1910 SPECIES RECORDED IN THE MERCANTOUR NATIONAL PARK}

1. Metasoma with a single visible tergal plate or, if two, with basal tergite much shorter than second along middorsal line (Fig. 11D) ......

- Metasoma with two large visible terga, subequal in length along middorsal line, but basal tergite $1 / 4-1 / 3$ smaller than second in lateral view (Fig. 11C)

2. Metasoma with two visible tergal plates; first metasomal tergite much shorter than second along middorsal line (Fig. 11D) Open radial cell with R1 and Rs parallel Apocharips Fergusson, 1986

- Metasoma with a single visible tergal plate Apocharips trapezoidea (Hartig, 1841)

Distal half of the metasoma with a punctate area; F1 slightly longer than pedicel, slightly curved; F2 or F3 each shorter than F1 (Fig. 10B)..... Dilyta subclavata Förster, 1869

3. Mesopleuron with a basal longitudinal furrow (Fig. 11A) Phaenoglyphis Förster, 1869........4

- Mesopleuron without longitudinal furrow (Fig. 11B) Alloxysta Förster, 1869......13

4. Notaulus present, at least in posterior half of mesoscutum; mesoscutum sculptured or not ......................... 5

— Notaulus completely absent, mesoscutum smooth and shiny.....

5. Mesoscutum with imbricated sculpture ........ Phaenoglyphis evenhuisi Pujade-Villar \& Paretas-Martínez, 2006

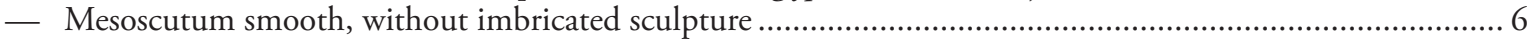

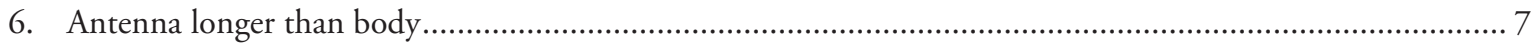

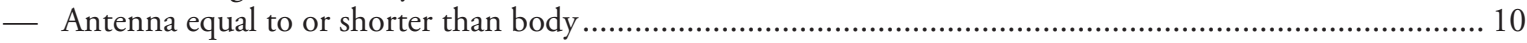

7. Rhinaria and flagellum thickening begin from different flagellomeres................................................. 8

— Rhinaria and flagellum thickening begin from the same flagellomere ................................................. 9

8. Female: flagellum thickening beginning from F2; F1 $2.1 \times$ as long as pedicel (Fig. 10D); notaulus clearly marked along their entire length; longitudinal carinae of metascutellum do not branch at base. Male: thickening and rhinaria begin from F2; F1 strongly curved, F2 shorter than F3, F3 subequal to F4

Phaenoglyphis americana Baker, 1896

- Female: flagellum thickening beginning from F3, F1 $1.3 \times$ longer than pedicel (Fig. 10L); notaulus deeply excavated anteriorly and weakly posteriorly; longitudinal carinae of metascutellum branching at base. Male: thickening begin from F3 and rhinaria from F5; F1 curved, F2 subequal to F3, F3 shorter than F4.

Phaenoglyphis fuscicornis (Thomson, 1877)

9. Female: Rhinaria and flagellum thickening begin from F1; F2 subequal to F3 (Fig. 10H); scutellar foveae with open at the bottom; radial cell $2.7 \times$ longer than wide; Rs slightly curved. Male unknown

Phaenoglyphis longicornis (Hartig, 1840)

- Female: Rhinaria and flagellum thickening begin from F2; F2-F3 different in length (Fig. 10I); scutellar foveae slightly fused; radial cell $2.9 \times$ longer than wide. Male unknown ......

Phaenoglyphis stenos Andrews, 1978

10. Female: F1 subequal or shorter than pedicel, F2-F4 distincly unequal in length (Fig. 10C); small and oval scutellar foveae completely defined and separated by a thick carina. Male unknown....

Phaenoglyphis abbreviata (Thomson, 1877)

- Female: F1 longer than pedicel, proportion between flagellomere and shape of scutellar foveae different..... 11

11. Female: F2 shorter than F3, F3-F4 subequal in length (Fig. 10K); mesoscutum with a line of setae near each notaulus, notauli barely distinct; scutellar foveae well-defined and with two apical lines. Male unknown ........ Phaenoglyphis salicis (Cameron, 1883)

- Female: F2-F4 subequal in length (Fig. 10G); mesoscutum with central area glabrous, notaulus deeper posteriorly than anteriorly; scutellar foveae slightly open anteriorly. Male unknown.....

Phaenoglyphis gutierrezi Andrews, 1978

12. Radial cell partially open along anterior margin (Fig. 9C); scutellar foveae rounded and slightly fused apically ............................................................................................. Phaenoglyphis villosa (Hartig, 1841)

- Radial cell closed (like Fig. 9D); scutellar foveae rounded, separated by a carina and open basally Phaenoglyphis calverti Andrews, 1978

13. Radial cell open or partially open

- Radial cell closed 


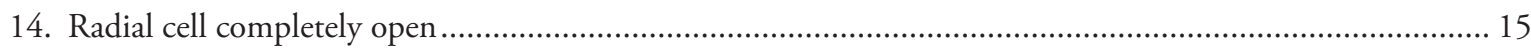

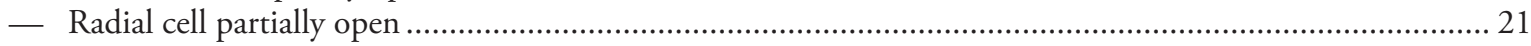

15. Propodeal carinae present forming a thick plate........................................................................... 16

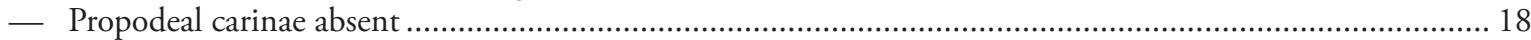

16. Pronotal carinae absent (Fig. 7D); F1 subequal in length to pedicel (Fig. 7B); radial cell $2.4 \times$ longer than wide (Fig. 7C) Alloxysta franca Ferrer-Suay \& Pujade-Villar, n. sp.

- Pronotal carinae present; F1 longer than pedicel; radial cell less than $2.4 \times$ longer than wide......

17. F2 longer than F1; F2 longer than F3 (Fig. 2A) Alloxysta abdera Fergusson, 1986

- F2 shorter than F1; F2 subequal to F3 (Fig. 8D) Alloxysta pilae Ferrer-Suay, n. sp.

18. Pronotal carinae absent; F2 longer than F1 (Fig. 2R). Alloxysta proxima Belizin, 1962

- Pronotal carinae present; F2 shorter or subequal to F1

19. F2 subequal to F1 (Fig. 4C); radial cell $3.8 \times$ longer than wide (Fig. 4A).....

- F2 shorter than F1; radial cell shorter than $3.8 \times$ longer than wide Alloxysta alpina Ferrer-Suay \& Pujade-Villar, n. sp.

20. F2 shorter than F3 (Fig. $2 \mathrm{~N}$ ); radial cell $2.9 \times$ longer than wide (Fig. $3 \mathrm{~N}$ )

— F2 longer than F3 (Fig. 2C); radial cell $2.7 \times$ longer than wide (Fig. 3C)

Alloxysta nigrita (Thomson, 1862) Alloxysta brachycera Hellén, 1963

21. Propodeal carinae absent

- Propodeal carinae present

22. Female: F1 subequal to F2, F2 longer than F3, F3 subequal to F4 (Fig. 2K). Male: F2 and F3 curved, F1 subequal to F2, F2 longer than F3, F3 longer than F4; radial cell $3.0 \times$ longer than wide (Fig. 3K) .....

Alloxysta macrophadna (Hartig, 1841)

- Female: F1 longer than F2, F2 shorter than F3, F3 shorter than F4 (Fig. 2O). Male: without any curved flagellomere, F1 longer than F2, F2 longer than F3, F3 shorter than F4; radial cell $2.7 \times$ longer than wide (Fig. 3O). Alloxysta obscurata (Hartig, 1840)

23. F1 subequal to pedicel. 24

- F1 longer than pedicel. 25

24. Propodeal carinae not protruding (Fig. 6F); radial cell $2.1 \times$ longer than wide (Fig. 3G)

- Propodeal carinae protruding and clearly visible; radial cell $2.5 \times$ longer than wide (Fig. 3Q) Alloxysta postica (Hartig, 1841)

25. Rhinaria and flagellum thickening begin from F3 (Fig. 2J); radial cell $2.6 \times$ longer than wide (Fig. 3J) Alloxysta longipennis (Hartig, 1841)

- Rhinaria and flagellum thickening begin from F4; radial cell less than $2.6 \times$ longer than wide

26. Female and male: F1 longer than F2, F2 subequal to F3 (Fig. 2E); radial cell $2.3 \times$ longer than wide (Fig. 3E) Alloxysta castanea (Hartig, 1841)

- Female: pedicel-F3 subequal in length (Fig. 2L). Male: F1 longer than pedicel and F2, F2 subequal to F3; radial cell $2.0 \times$ longer than wide (Fig. 3L)....... Alloxysta melanogaster (Hartig, 1840)

27. Propodeal carinae present 28

- Propodeal carinae absent..... 31

28. Pronotal carinae present 29

- Pronotal carinae absent 33

29. Female: F1 subequal to pedicel (Fig. 2B). Male: F2 slightly curved; radial cell $2.3 \times$ longer than wide (Fig. 3B)..... Alloxysta arcuata (Kieffer, 1902)

- Female: F1 longer than pedicel. Male: without any curved flagellomere or F1-F3 slightly curved; radial cell more than $2.3 \times$ longer than wide 
30. Female: F2 shorter than F3 (Fig. 2S). Male: rhinaria begin from F1, pedicel-F3 subequal and slightly curved; propodeal plate with slightly curved lateral sides; radial cell $2.7 \times$ longer than wide in female and $2.4 \times$ longer than wide in male (Fig. 3S) .......................................................................... Alloxysta pusilla (Kieffer, 1902)

- Female: F2 subequal to F3 (Fig. 2P). Male: rhinaria begin from F2, pedicel-F3 unequal, without any curved flagellomere; propodeal plate with strongly curved lateral sides; radial cell $2.4 \times$ longer than wide in both male and female (Fig. 3P) Alloxysta pilipennis (Hartig, 1840)

31. Head yellowish; F2-F4 subequal in length (Fig. 2T); radial cell $3.0 \times$ longer than wide (Fig. 3T); propodeum without setae in the longitudinal area where the carinae are present in other Charipinae (Fig. 6B) .....

Alloxysta victrix (Westwood, 1833)

- Head brown; F2-F4 distinctly unequal; radial cell less than $3.0 \times$ longer than wide; propodeum entirely setose 32

32. Female: rhinaria and club-shaped begin from F3; F1 subequal to F2, F2 shorter or subequal to F3 (Fig. 2F). Male: F1-F3 distinctly unequal; radial cell $2.5 \times$ longer than wide (Fig. 3F)

Alloxysta circumscripta (Hartig, 1841)

- Female: rhinaria and flagellum thickening begin from F3 or F4; F1 longer than F2, F2 subequal to F3 (Fig. 2I). Male: F1-F3 curved; radial cell $2.7 \times$ longer than wide (Fig. 3I) ......... Alloxysta consobrina (Zetterstedt, 1838)

33. Antennae shorter than body length; F1 shorter than pedicel; F1-F3 subequal in length (Fig. 2D); radial cell $2.1 \times$ longer than wide (Fig. 3D) ........................................................... Alloxysta brevis (Thomson, 1862)

- Antennae longer than body length; F1 subequal or longer than pedicel; F1-F3 distinctly unequal in length; radial cell longer than $2.1 \times$ longer than wide......

34. Female: F1 longer than pedicel; F1-F3 subequal in length (Fig. 2H). Male: F3 curved.

Alloxysta fracticornis (Thomson, 1862)

- Female: F1 subequal to pedicel; F1 longer than F2, F2 subequal to F3 (Fig. 2M). Male: without any curved flagellomere. Alloxysta mullensis (Cameron, 1883)

\section{Acknowledgements}

This research was supported by the project CGL2011-22889 of the Ministerio de Ciencia e Innovación (Spain) and the grant AP2009-4833 of the Ministerio de Educación (Spain).

Thanks to the European Distributed Institute of Taxonomy (EDIT) for supporting this study as a part of the All Taxa Biodiversity Inventory + Monitoring Project (ATBI+M). We warmly thank Louis Deharveng from the Muséum national d'Histoire naturelle (ISYEB) who organized and supervised the "Terrestrial Invertebrates Fieldwork Module" as well as the guards of the Mercantour National Park, notably J. Molto, M. Torjman and E. Menissieux, who kindly collected the Malaise trap samples every two weeks along the four to five months of the sampling periods. We are also very grateful to Magdalena Czyrnek and Thomas Théry, who sorted the specimens to the family level. We thank the reviewers that contribute to improve our manuscript.

\section{BIBLIOGRAPHY}

ANDREWS F. G. 1978 - Taxonomy and host specificity of Nearctic Alloxystinae with a catalogue of the World species (Hymenoptera: Cynipidae). Ocasional Papers in Entomology 25: 1-128.

BAKER C. F. 1896 - New American parasitic Cynipidae (Allotriinae). Canadian Entomologist 28: 131-135.

Belizin V. I. 1962 - New Parasitoid Cynipoidea species (Hymenoptera) from a Far East. Communications of the Far East Branch of the Russian Academy os Sciences (Siberian Section) 16: 125-129.

CAMERON P. 1883 - Descriptions of sixteen new species of parasitic Cynipidae, chiefly from Scotland. Transactions of the Entomological Society of London 16 (4): 365-374.
Cavro E. 1954 - Catalogue des Hyménoptères du département du Nord et des régions limithrophes. III. Térébrants (Parasites byte tarières). Bulletin de la Sociéte entomologique du Nord de la France, 75, suppl. 134 p.

Dalla Torre K.W. \& KiefFer J. J. 1910. — Das Tierreich XXIV: Cynipidae. R. Friedlander \& Sons, Berlin. 24: 1-891.

De Gaulle J. 1908. - Catalogue Systématique \& Biologique des Hyménoptères de France. Librairie Paul Klincksieck, Paris, 171 p.

Deharveng L., Bedos A., Daugeron C., Villemant C. \& Judson M. L. I. 2015. - Organization, usefulness and limitations of an ATBI (All Taxa Biodiversity Inventory): the inventory of terrestrial invertebrates in the Mercantour National Park, in Daugeron C., Deharveng L., Isaia M., Villemant C. \& Judson M. (eds), Mercantour/Alpi Marittime All Taxa Biodiversity Inventory. Zoosystema 37 (1): 9-30. http://dx.doi.org/10.5252/z2015n1a1

FERGUSSON N. D. M. 1986. — Charipidae, Ibaliidae and Figitidae (Hymenoptera: Cynipoidea). Handbook of Identification British Insects 8 (1c): 1-55.

Ferrer-Suay M., Paretas-Martínez J., Selfa J. \& Pujade-VilLAR J. 2012a. - Taxonomic and synonymic world catalogue of the Charipinae and notes about this subfamily (Hymenoptera: Cynipoidea: Figitidae). Zootaxa 3376: 1-92.

Ferrer-Suay M., Selfa J. \& Pujade-Villar J. 2012b. — Taxonomic revision of the Alloxysta brevis group (Cynipoidea: Figitidae: Charipinae). Boletin de la Sociedad Entomológica Aragonesa 51: 237-259

Ferrer-Suay M., Selfa J. \& Pujade-Villar J. 2013. - Revision of Thomson and Zetterstedt collections of Alloxysta genus deposited in Lund Museum of Zoology (Sweden). Entomologisk Tidskrift 134: 77-102.

FÖRSTER A. 1869. - Ueber die Gallwespen. Verhandlungen der Zoologisch-Botanischen Gesellschaft in Wien 19: 327-370.

HaRTig T. 1840. — Ueber die Familie der Gallwespen. Zeitschrift für Entomologie (Germar) 2: 176-210.

HARTIG T. 1841. - Erster nachtrag zur naturgeschichte der Gallwespen. Zeitschrift für Entomologie (Germar) 3: 322-358. 
Hellén W. 1963. — Die Alloxystininen Finnlands (Hymenoptera: Cynipidae) Fauna Fennica 15: 1-23.

KiEFFER J. J. 1902a. — Description de quelques Cynipides nouveaux ou peu connus et de deux de leurs parasites (Hymenoptères). Bulletin de la Société d'Histoire naturelle de Metz 10: 1-18.

KIEFFER J. J. 1902b. — Les Cynipides (Suite), 3e Tribu: Allotriines (Allotriinae), [Charipinae in 5-78], in ANDRÉ E. (ed.), Species des Hyménoptères d'Europe \& d'Algérie, vol. 7, part 2, 748 p.

KiefFer J. J. 1904a. — Les Cynipides (Suite), 3e Tribu: Allotriines (Allotriinae), [Charipinae in: 592-602], in ANDRÉ E. (ed.), Species des Hyménoptères d'Europe o d'Algérie, vol. 7, part 2, 748 p.

KIEFFER J.J. 1904b. - Description de quelques Cynipides exotiques dont l'un forme un genre nouveau. Bulletin de la Société d'Histoire naturelle de Metz 2 (11): 59-66.

Menke A. S. \& Evenhuis H. H. 1991. - North American Charipidae: key to genera, nomenclature, species checklists, and a new species of Dilyta Förster (Hymenoptera: Cynipoidea). Proceedings of the Entomological Society of Washington 93: 136-158.

Paretas-Martínez J. \& Pujade-Villar J. 2006. - Two genera of Charipinae (Hymenoptera: Figitidae) from Australia: revision of the genus Thoreauana Girault, 1930 and description of Dilapothor n. gen. Australian Journal of Entomology 45: 219-226.

Paretas-Martínez J., Arnedo M. A., Melika G., Selfa J., SecoFernándeZ M. V., FÜlÖP D. \& PujAde-VILlar J. 2007a. — Phylogeny of the parasitic wasp subfamily Charipinae (Hymenoptera, Cynipoidea, Figitidae). Zoologica Scripta 36: 153-172.

THOMSON C. G. 1862. — Forsok till uppstallning och beskrifning af Sveriges Figiter. Öfuersigt af Kongliga Svenska Vetenskapsakademiens forrhandlingar 18: 395-420.

Thomson C. G. 1877. — Öfversikt af Sveriges Cynips-arter. Opuscula Entomologica 8: 778-820.

WESTWOOD J. O. 1833. - Notice of the habits of a Cynipidous insect parasitic upon the Aphis rosae with descriptions of several other parasitic Hymenoptera. Magazine of Natural History 6: 491-497.

ZetTeRstedt J. W. 1838. - Insecta Lapponica descripta: Hymenoptera. Voss, Lipsiae: 315-476.

Submitted on 20 March 2014; accepted on 17 October 2014; published on 27 March 2015. 